\title{
Multiproduct Firms, Export Product Scope and Trade Liberalization: The Role of Managerial Efficiency
}

\author{
Larry Qiu \\ Miaojie $\mathrm{Yu}^{*}$ \\ University of Hong Kong \\ Peking University
}

May 5, 2013

\begin{abstract}
This paper provides a theoretical and empirical analysis on the effects of one-sided trade liberalization on firms' export product scope. The model explicitly incorporates the cost of managing production and sales in addition to the usually-modeled production cost. The analysis predicts that the home country's tariff cut reduces all home firms' export product scope; whereas in response to the foreign country's tariff cut, a home firm's export product scope expands (shrinks) if the firm's management cost is low (high), independent of the firm's production cost. These predictions are confirmed by our empirical analysis based data of Chinese firms from 2000 to 2006.
\end{abstract}

JEL: F12, F13, F15

Keywords: Multiproduct firm; Management cost; Export product scope; Trade liberalization; China

(Very Preliminary)

\footnotetext{
*Qiu: School of Economics and Finance, the University of HOng Kong, Hong Kong, Tel: (852)28591043, Email: larryqiu@hku.hk. Yu: China Center for Economic Research (CCER), Peking University, Beijing 100871, China, Tel: (86)10-62753109, E-mail: mjyu@ccer.pku.edu.cn.
} 


\section{Introduction}

Multiproduct firms contribute to a large percent of production and international trade worldwide. They frequently adjust their product scope in response to changes in economic environment and policies (Bernard et al., 2009). Product scope adjustments affect firm and industry average productivity (Bernard et al., 2010 and 2011). The recent research has increased our understanding about firms' adjustment in respose to trade liberalization (see the most recent review in Qiu and Zhou, 2013). However, our knowledge of this issue is still very limited. This paper goes one step further to examine how firms adjust their export product scope (not the total product scope) in response to one-sided trade liberalization, namely, domestic tariff cut or foreign tariff cut, respectively.

As sythenized by Qiu and Zhou (2013), the collective wisdom from the literature at the present stage is that in response to globalization, which is represented by bilateral trade liberalization, high productivity firms may expand their product scope while low productivity firms definitely reduce their porduct scope. A firm's optimal product scope is jointly determined by marginal cost of adding new product lines, which is strictly increasing, and the marginal benefit of adding new product lines, which is (weakly) decreasing under the core competency assumption. Bilateral trade liberalization imposes two conflicting forces on a firm's marginal product: domestic trade liberalization exerts a negative impact (the competition effect) but foreign country's trade liberalization gives a positive opportunity (the market expansion effect). If a firm is very productive, its marginal product is also quite productive, and thus, the positive effect dominates and the firm expands its product scope. In contrast, if a firm is not very productive, the negative effect dominates and so the firm reduces its product scope. Unlike the existing studies which always look at the outcome of the joint effects [NOTE: double check each paper], the present paper analyzes each effect separately, which can be captured by one-sided trade liberalization, either domestic or foreign. Although in the real world, multilateral trade liberalization 
exists through multilateral trade negotiations under the framework of the GATT and bilateral trade liberalization exists especially under free trade agreements, one-sided trade liberalization or asymmetric bilateral trade liberalization often occur. For example, since 1979 when China started to open its economy, China has unilaterally reduced its tariffs from the average above 40 percent to around 9 percent. This evidence indicates that the picture would not be complete if we do not examine how firms adjust their product scope in response to one-sided trade liberalization. Another departure from the literature is that we focus on the product scope actually traded, that is, a firm's export product scope (the number of products exported), rather than a firm's total product scope (the number of products produced).

As the existing studies seem to suggest that the qualitative effects of each one-sided trade liberalization on all firms, high and low productivity, are the same, we choose a homogenouse-firm model in order to sharpen our focus on the role of managerial efficiency. [NOTE: we will revise the introduction from here] This paper examines how unilateral trade liberalization affects Chinese firms' export product scope. Unilateral trade liberalization allows us to see the forces leading to the scope adjustment much more clearly. In particular, we analyze the effect of Chinese tariff cuts on Chinese firms' export product scope adjustment and that of foreign countries' tariff cuts on Chinese firms' export product scope. In our theoretical model with only two countries, China and Foreign, the Chinese firms are identical, but each has heterogeneous products with decreasing productivity. Each firm's decision is on its optimal product scope (total number of products to produce) and optimal export product scope (total number of products to export). The domestic tariff cut lowest the profit of every product of a Chinese firm, which induces the firm to drop its unprofitable marginal products, hence reducing a firm's product scope. If the cut is drastic, more products will be dropped and even some of the products for export will also be dropped, resulting in reduction in a firm's export product scope. Hence, domestic tariff cut affects export market. On the other hand, the foreign country's tariff cut raises the 
profit of each export product of a Chinese firm. The direct effect should induce a Chinese firm to expand its export product scope as some previously unprofitable products become profitable in the export market. However, the tariff cut also induces a price drop of every exported product, which makes the market competition tougher. This competition effect tends to lower every product's profit. Hence, whether the marginal export products will see an increase in profitability or drop in profitability depends on the relative magnitudes of the direct (positive) effect from tariff cut and the indirect (negative) effect from intense market competition. We find that the direct effect dominates when the firm's core competency is very efficient whereas the indirect effect dominates in the opposite case. That is, in response to the foreign country's tariff cut, a Chinese firm expands its export product scope if the firm's core competency is very efficient but reduces its export product scope if its core competency is not very efficient.

We test our theoretical predictions on Chinese exporters. As there are hundreds of tariff lines and Chinese firms export to more than a hundred foreign markets, to better capture the trade liberalization impacts, we construct the firm specific home tariffs, i.e., the weighted average of those Chinese tariffs relevant to a firm's product lines, and the firm specific foreign tariffs, i.e., the weighted average of those tariffs from countries on products that are relevant to a firm's export products and markets. Our regression results show that in response to Chinese tariff cuts, Chinese firms reduce their export product scope; and in response to foreign tariff cuts, Chinese firms also reduce their export product scope.

Theoretical studies in the literature of multiproduct firms generally predict that in response to bilateral trade liberalization, all firms (low productive and high productive) reduce their product scope (Arkolakis and Muendler, 2010; Baldwin and Gu, 2009; Bernard et al., 2011; Dhingra, 2011; Eckel and Neary, 2010; Feenstra and Ma, 2008; Mayer et al., 2011). The basic intuition is that every firm's marginal products are very inefficient, and like inefficient single-product firms being driven out of the industry after trade liberaliza- 
tion (Melitz, 2003; Melitz and Ottaviano, 2008)), those marginal products will be dropped, resulting in a reduction in product scope. However, Qiu and Zhou (2013) pointed out that the result may be different if firms face increasing cost of introducing more product lines. A firm continues to introduce more products until the marginal cost of introducing product is equal to the market profit of the additional product. If the marginal cost of product introduction increases very fast, a very productive firm's marginal product must also be very efficient. As efficient products benefit from trade liberalization, the most productive firms will expand their product scope in response to trade liberalization. In contrast, the present paper focuses on unilateral trade liberalization. It shows that it is possible that both domestic tariff cut and foreign tariff cut, which seem to have opposite forces, have the same effects on the exporters' product scope adjustment: reducing export product scope.

Most empirical studies of multiproduct firms have found significant impacts of trade liberalization on firms' scope choices. Despite the fact that most theoretical studies focus on bilateral trade liberalization, many empirical studies are about unilateral trade liberalization. Dhingra (2011) showed that in Thailand during 2003-2006, less export-oriented domestic firms increased their product lines in response to a unilateral tariff cut while more export-oriented domestic firms reduced their product lines. Iacovone and Javorcik (2010) documented that a substantial number of Mexican firms developed new products for export as a response to improved access to foreign markets. Bernard et al. (2011) demonstrated that U.S. firms exposed to more tariff reductions under the Canada-U.S. Free Trade Agreement reduced the number of products they produce relative to firms exposed to fewer tariff reductions. ${ }^{1}$ Goldberg et al. (2010) shown that during the 1989-2003 period when profound trade and other reforms took place in India, Indian firms added

\footnotetext{
${ }^{1}$ There are also empirical studies on bilateral or multilateral trade liberalization. Baldwin and $\mathrm{Gu}$ (2009) found that tariff cuts between 1973 to 1997 induced scope contraction by small or non-exporting Canadian firms, but had no effect on large or exporting firms. Berthou and Fontagne (2011) found that after the eurozone was established in 1999 the most productive French firms increased their export product scope in the eurozone destinations while less-productive French firms reduce their export product scope.
} 
more product lines than they dropped, and the dropping was unrelated to tariff reduction. Clearly, the previous empirical findings have been far from complete or conclusive. The empirical finding of this study contributes to the understanding of this phenomenon. ${ }^{2}$

The rest of the paper is organized as follows. In Section 2, we introduce the theoretical model. In Section 3, we conduct an equilibrium analysis and derive results related to the effects of trade liberalization on firms' export product scope. In Section 4, we use Chinese data to test the main theoretical predictions. Section 5 provides some concluding remarks.

\section{Theoretical Model}

\subsection{Technologies}

Consider a world with two countries, China and Foreign (the rest of the world). Let us first describe the economy in China. There are two industries, one being the numeraire good industry and the other being the differentiated products industry. Differentiated products are produced by $n$ symmetric (identical) firms and the numeraire good is produced by atomic firms. ${ }^{3}$ If a firm produces just one product (its core competency), its marginal cost is $c$.

A firm in the differentiated goods industry can produce multiple varieties or products. Suppose that a firm decides to introduce a set of products with measure $s$. We index the firm's core competency as product 0 and others in descending efficiency in $[0, s]$, which also captures the situation in which products further away from the core competency become less efficient. Let the unit cost of producing the $i$ th product be $c_{i}=c+\theta i, \theta>0$. The unit cost of producing the core competency is $c$. Introducing a product is costly. If a firm

\footnotetext{
${ }^{2}$ Manova and Zhang (2012) also used Chinese data to explore multiproduct firms' behavior. An important feature of their study is the linkage between multiple products and multiple quality. Echel et al. (2011) also shared the same feature based on Mexican firms.

${ }^{3}$ We consider identical firms for simplicity as our focus is not on the difference between different firms. Our empirical part shows that the behaviors between high-productivity firms and low-productivity firms are not qualitatively different.

We focus on free entry at the product level and so we assume fixed number of firms, i.e., do not consider free entry at the firm level. We will discuss the implications of relaxing this assumption later.
} 
introduces $s$ products, there is a fixed cost equal to $k s$, where $k>0$.

There is a cost of managing production and sales in both the domestic market and overseas market. Assume that a unit management cost is $m$. So, if a firm sells $q$ units of a product to a market, it needs to spend $m q$ on management.

As our focus is on the Chinese firms, let us simplify the situation of the foreign firms. In particular, assume that there are $n^{*}$ identical foreign firms; all have the same marginal cost of production, which is assumed to be zero; each firm produces a single product; and there is not cost of managing production and sales. ${ }^{4}$

\subsection{Product Markets}

Following Melitz and Ottaviano (2008), we assume that there are $Z$ identical consumers in China, each having a quasi-linear preference for the numeraire good and all varieties from the differentiated goods industry

$$
U=Q_{0}+\alpha \int_{i \in \Omega} q_{i} d i-\frac{1}{2} \beta\left(\int_{i \in \Omega} q_{i} d i\right)^{2}-\frac{1}{2} \gamma \int_{i \in \Omega} q_{i}^{2} d i
$$

where $\alpha, \beta, \gamma>0, Q_{0}$ is the consumption of the numeraire good, $\Omega$ is the set of all varieties sold in the Chinese market, and $q_{i}$ is the consumption of variety $i$. We treat $i$ as a continuous variable for mathematical convenience. A consumer maximizes her utility subject to a budget constraint. As a result, the market demand for variety $i$ by all $Z$ consumers is $p_{i}=\alpha-\frac{\beta}{Z} \int_{j \in \Omega} q_{j} d j-\frac{\gamma}{Z} q_{i}$. For a given $\gamma$, when $\beta$ is larger, other varieties' outputs reduce the demand for variety $i$ by a larger amount, meaning that the substitution between varieties is stronger. Therefore, $\beta$ measures substitutability between varieties: larger $\beta$ means stronger substitution.

The set of varieties, $\Omega$, is large and thus, the seller of variety $i$ regards itself as a small monopolist of variety $i$, but whose decision has no direct effect on other products. ${ }^{5}$ Then,

\footnotetext{
${ }^{4}$ In this paper, we use asterisk $(*)$ to indicate variables of the foreign country.

${ }^{5}$ Following most studies in the literature, we do not consider carniberlization, which is about strategic competition among varieties of the same firm.
} 
competition between products is totally captured by the vertical intercept of the demand function. In particular, the demand function for variety $i$ is

$$
p_{i}=A-b q_{i}, \text { where } A=\frac{\alpha \gamma+\beta P}{\beta M+\gamma} \text { and } b=\frac{\gamma}{Z}
$$

In the above demand function, $p_{i}$ is the price of variety $i, M$ is the measure of $\Omega$, and $P=\int_{i \in \Omega} p_{i} d i$ is the aggregate price of all varieties. The slope $b$ is exogenous, but the intercept $A$ is endogenous, depending on the degree of product substitution $(\beta)$ and the degree of product market competition (captured by the endogenous $P$ and $M$ ).

The foreign country also has $Z$ consumers and the same demand structure as China. In particular, the demand function for variety $i$ is

$$
p_{i}=A^{*}-b q_{i}, \text { where } A^{*}=\frac{\alpha \gamma+\beta P^{*}}{\beta M^{*}+\gamma} \text { and } b=\frac{\gamma}{Z} .
$$

In this demand function, $M^{*}$ is the measure of the set of varieties sold in the foreign

market, which is denoted by $\Omega_{F}$, and $P^{*}=\int_{i \in \Omega_{F}} p_{i} d i$ is the aggregate price of all varieties in the foreign market.

Assume that tariffs take the form of iceberg transport cost. Let $t(>1)$ and $t^{*}(>1)$ denote China's tariff and the foreign country's tariff on the differentiated goods imports, respectively. Then, $t$ units of a product need to be produced by a foreign firm to sell one unit in the Chinese market and $t^{*}$ units of a product need to be produced by a Chinese firm to sell one unit in the foreign market. There is free trade in the numeraire good industry.

\section{Equilibrium Analysis}

We should first derive the short-run equilibrium in which there is no entry and exit in the differentiated goods industry. That is, the number of Chinese firms, $n$, and the number of foreign firms, $n^{*}$, are fixed. In Subsection 3.3, we will examine the long-run equilibrium which accommodates free entry and exit. 


\subsection{Short-run Equilibrium}

Let us first focus on the Chinese firms' decisions. Each firm takes $A$ and $A^{*}$ as given when making its decisions. Suppose that a firm has a product with marginal cost equal to $c_{i}$. Then, if the product is sold to the domestic market, the optimal output maximizes the profit of this product derived from the domestic market. The optimization problem is

$$
\max _{q \geq 0} \pi_{H}\left(c_{i}\right) \equiv(A-b q) q-\left(m+c_{i}\right) q
$$

The optimal quantity, price and profit for this product are, respectively,

$$
q_{H}\left(c_{i}\right)=\frac{A-m-c_{i}}{2 b}, p_{H}\left(c_{i}\right)=\frac{A+m+c_{i}}{2}, \text { and } \pi_{H}\left(c_{i}\right)=\frac{1}{4 b}\left(A-m-c_{i}\right)^{2} .
$$

Stronger demand (i.e., a larger $A$ ) leads to a larger output, a higher price and a larger profit.

If the product is sold in the foreign market, the optimal output maximizes the profit of this product derived from the foreign market. Mathematically, we have

$$
\max _{q \geq 0} \pi_{F}\left(c_{i}\right) \equiv\left(A^{*}-b q\right) q-m q-c_{i} t^{*} q
$$

The optimal quantity, price and profit of this product are, respectively,

$$
q_{F}\left(c_{i}\right)=\frac{A^{*}-m-c_{i} t^{*}}{2 b}, p_{F}\left(c_{i}\right)=\frac{A^{*}+m+c_{i} t^{*}}{2}, \text { and } \pi_{F}\left(c_{i}\right)=\frac{1}{4 b}\left(A^{*}-m-c_{i} t^{*}\right)^{2} \text {. }
$$

We now turn to derive the optimal total product scope and optimal export product scope. Suppose that a firm decides to introduce a range of products, $[0, s]$, which is called the firm's total product scope. We will provide the condition later to focus on the case where a firm will not introduce a product which is exported to the foreign market, but not sold to the domestic market. Then, a firm's export products are a subset of its total products. Let $[0, e]$ be the set of all its export products, called the firm's export product scope. ${ }^{6}$ If $e<s$, then there exist some products $(i \in(e, s])$ which are sold in the domestic

\footnotetext{
${ }^{6}$ Due to the decreasing efficiency in $[0, s]$, if a firm exports product $i \in[0, s]$, it will export all products $j<i$.
} 
market not exported.

We can write a firm's total profit as a function of $s$

$$
\pi(s)=\int_{0}^{s} \frac{1}{4 b}\left(A-m-c_{i}\right)^{2} d i+\int_{0}^{e} \frac{1}{4 b}\left(A^{*}-m-c_{i} t^{*}\right)^{2} d i-k s .
$$

The firm chooses $s$ to maximize the above profit. Let us focus on the more interesting case in which $k$ is not too big such that $e<s$. Then, the first order condition is

$$
\pi^{\prime}(s)=\frac{1}{4 b}(A-m-c-\theta s)^{2}-k=0 .
$$

The second order condition, $\pi^{\prime}(s)<0$, is clearly satisfied. We obtain the optimal total product scope

$$
\tilde{s}=\frac{A-m-c-2 \sqrt{b k}}{\theta} .
$$

The total product scope is larger with stronger market demand $(A)$, lower resource requirement to manage the production and sales $(m)$, lower cost of product introduction $(k)$, higher productivity of the core competency $(c)$, and slower decline of productivity of the non-core competency products $(\theta)$.

Given $e<\tilde{s}$, the optimal export product scope is simply determined by the zero profit condition of the least efficient product's export, i.e., $\pi_{F}(\tilde{e})=0$, which yields

$$
\tilde{e}=\frac{A^{*}-m-c t^{*}}{\theta t^{*}} \text {. }
$$

The export product scope is larger with stronger market demand $\left(A^{*}\right)$, lower resource requirement to manage the production and sales $(m)$, higher productivity of the core competency $(c)$, slower decline of productivity of the non-core competency products $(\theta)$, and lower foreign tariff $\left(t^{*}\right)$.

We now turn to the foreign firms. In the Chinese market, a foreign firm chooses its output to maximize its profit $\left(A-b q_{H}^{*}\right) q_{H}^{*}-t q_{H}^{*}$. The optimal quantity, price and profit of the firm in the Chinese market are, respectively,

$$
q_{H}^{*}=\frac{A-t}{2 b}, p_{H}^{*}=\frac{A+t}{2}, \text { and } \pi_{H}^{*}=\frac{1}{4 b}(A-t)^{2} .
$$


In the foreign market, the foreign firm chooses output to maximize its profit $\left(A^{*}-\right.$ $\left.b q_{F}^{*}\right) q_{F}^{*}$. The optimal quantity, price and profit of the firm in the foreign market are, respectively,

$$
q_{F}^{*}=\frac{A^{*}}{2 b}, p_{F}^{*}=\frac{A^{*}}{2}, \text { and } \pi_{F}^{*}=\frac{1}{4 b} A^{* 2} .
$$

Finally, we determine the equilibrium $A$ and $A^{*}$. To determine $A=\frac{\alpha \gamma+\beta P}{\beta M+\gamma}$, we need to first calculate $M$ and $P$. Recall that all Chinese firms are identical and there is no free entry and exit. Thus, $M=\tilde{s} n+n^{*}$.

From (4), we obtain the aggregate price of each Chinese firm in the Chinese market

$$
\tilde{p}_{H}=\int_{0}^{\tilde{s}} p_{H}\left(c_{i}\right) d i=\frac{1}{2}(A+m+c) \tilde{s}+\frac{1}{4} \theta \tilde{s}^{2} .
$$

Each foreign firm's price in the Chinese market is given in (10). Thus, the aggregate price in the Chinese market is

$$
P=\frac{1}{4}\left[2(A+m+c) n \tilde{s}+\theta n \tilde{s}^{2}+2(A+t) n^{*}\right] .
$$

Using the above results in $A=\frac{\alpha \gamma+\beta P}{\beta M+\gamma}$ yields the following condition that determines the equilibrium $A$ :

$$
2\left(n^{*}+\delta+n \tilde{s}\right) A-\alpha \gamma-2(m+c) n \tilde{s}-\theta n \tilde{s}^{2}-2 t n^{*}=0 .
$$

By substituting in $\tilde{s}$ from (8) to the above equality, we obtain that the equilibrium $A$ is a solution to the following equation

$$
A^{2}+2\left[\left(n^{*}+\delta\right) \frac{\theta}{n}-m-c\right] A+\left[(m+c)^{2}-4 b k-2\left(n^{*} t-\alpha \delta\right) \frac{\theta}{n}\right]=0,
$$

where $\delta \equiv \frac{2 \gamma}{\beta}$ is used to simplify notation. Eliminating the negative value solution, we obtain the unique solution to $A$ as

$$
A=\sqrt{a_{0}}-\left(n^{*}+\delta\right) \frac{\theta}{n}+m+c
$$

where

$$
a_{0}=\left(n^{*}+\delta\right)^{2}\left(\frac{\theta}{n}\right)^{2}+2\left[\alpha \delta+n^{*} t-(m+c)\left(n^{*}+\delta\right)\right] \frac{\theta}{n}+4 b k
$$


In the foreign market, the total number of products sold is $M^{*}=\tilde{e} n+n^{*}$. The aggregate price of each Chinese exporter is

$$
\tilde{p}_{F}=\int_{0}^{\tilde{e}} p_{F}\left(c_{i}\right) d i=\frac{1}{2}\left(A^{*}+m+c t^{*}\right) \tilde{e}+\frac{1}{4} t^{*} \theta \tilde{e}^{2} .
$$

Each foreign firm's price is given in (11). Thus, the aggregate price in the foreign market is

$$
P^{*}=\frac{1}{2}\left(A^{*}+m+c t^{*}\right) \tilde{e} n+\frac{1}{4} t^{*} \theta \tilde{e}^{2} n+\frac{1}{2} A^{*} n^{*} .
$$

Using the above results in $A^{*}=\frac{\alpha \gamma+\beta P^{*}}{\beta M^{*}+\gamma}$ yields the following condition that determines the equilibrium $A^{*}$ :

$$
2\left(n^{*}+\delta\right) A^{*}-\alpha \gamma-2\left(m+c t^{*}\right) n \tilde{e}-\theta t^{*} n \tilde{e}^{2}=0
$$

Substituting in $\tilde{e}$ from (9) to the above condition, we obtain the following equation that determines the equilibrium $A^{*}$ :

$$
A^{* 2}+2\left[\left(n^{*}+\delta\right) \frac{\theta t^{*}}{n}-m-c t^{*}\right] A^{*}+\left[\left(m+c t^{*}\right)^{2}-\frac{2 \alpha \delta \theta t^{*}}{n}\right]=0,
$$

This condition yields the equilibrium $A^{*}$ (excluding the negative value solution) as below

$$
A^{*}=\sqrt{a_{0}^{*}}-\left(n^{*}+\delta\right) \frac{\theta t^{*}}{n}+m+c t^{*}
$$

where

$$
a_{0}^{*}=\left(n^{*}+\delta\right)^{2}\left(\frac{\theta t^{*}}{n}\right)^{2}+2\left[\alpha \delta-\left(m+c t^{*}\right)\left(n^{*}+\delta\right)\right] \frac{\theta t^{*}}{n} .
$$

In summary, the equilibrium $A$, given in (13), is a function of China's tariff $t$, and the equilibrium $A^{*}$, given in (15), is a function of the foreign tariff $t^{*}$. Substituting $A$ in (8) to obtain the optimal total product scope $\tilde{s}$ as a function of $t$. Substituting $A^{*}$ in (9) to obtain the optimal export product scope $\tilde{e}$ as a function of $t^{*}$.

Finally, we check the conditions for $\tilde{e}<\tilde{s}$ in equilibrium. A direct comparison results 
in the following inequality

$$
\begin{aligned}
& \sqrt{\left(n^{*}+\delta\right)^{2}\left(\frac{\theta}{n}\right)^{2}+2\left[\left(\alpha \delta-\delta m-m n^{*}\right)-c\left(n^{*}+\delta\right)+n^{*} t\right] \frac{\theta}{n}+4 b k}-\sqrt{4 b k} \\
& >\sqrt{\left(n^{*}+\delta\right)^{2}\left(\frac{\theta}{n}\right)^{2}+2\left[\left(\alpha \delta-\delta m-m n^{*}\right) \frac{1}{t^{*}}-c\left(n^{*}+\delta\right)\right] \frac{\theta}{n}} .
\end{aligned}
$$

The right-hand side of (17) is decreasing in $t^{*}$ if and only if $m<\frac{\alpha \delta}{n^{*}+\delta}$. To ensure $\tilde{e}<\tilde{s}$, we assume that (17) holds. In particular, we assume that $t^{*}$ is sufficiently large if $m<\frac{\alpha \delta}{n^{*}+\delta}$. Under this condition, $\tilde{e}$ will be quite small. If the Chinese firm is not very efficient in management, its export profit will not be large any way, and so $\tilde{e}$ will not be big. If, however, it is very efficient in management, its export profit will be large unless $t^{*}$ is large. Thus, a large $t^{*}$ helps control the size of $\tilde{e}$.

\subsection{Trade Liberalization}

We analyze two types of trade liberalization and their effects on the Chinese firms' export product scope. The first type of liberalization is the tariff reduction in China $(t)$, and the second type is the tariff reduction in the foreign country $\left(t^{*}\right)$.

Let us first look at $\frac{d \tilde{e}}{d t}$. Using the expression of $\tilde{e}$ from (9) and that of $A^{*}$ from (15) and (16) we immediately know that $t$ does not have any direct effect on $\tilde{e}$ when it is given by (9). However, this optimal $\tilde{e}$ is obtained under the condition $e<s$. The Chinese tariff cut may eventually lead to a condition under which this equality does not hold. Note, from (8), (13) and (14), we obtain

$$
\frac{d \tilde{s}}{d t}=\frac{1}{\theta} \frac{d A}{d t}=\frac{1}{2 \theta \sqrt{a_{0}}} \frac{d a_{0}}{d t}=\frac{n^{*}}{n \sqrt{a_{0}}}>0
$$

Hence, when there is a tariff cut in China, Chinese firms reduce their total product scope $(\tilde{s})$. When there are continuous tariff cuts, the product scope eventually will drops down to equal to the export product scope $(\tilde{e})$. Once $\tilde{e}=\tilde{s}$, the optimal product scope is no longer given in (8). We prove in Appendix that $\frac{d \tilde{s}}{d t}=\frac{d \tilde{e}}{d t}>0$. 
We next turn to $\frac{d \tilde{e}}{d t^{*}}$. From from (9), (15) and (16), we obtain

$$
\tilde{e}=\sqrt{\left(n^{*}+\delta\right)^{2} \frac{1}{n^{2}}+2\left[\alpha \delta-\left(m+c t^{*}\right)\left(n^{*}+\delta\right)\right] \frac{1}{n \theta t^{*}}}-\left(n^{*}+\delta\right) \frac{1}{n} .
$$

Thus,

$$
\frac{d \tilde{e}}{d t^{*}}\left\{\begin{array}{cc}
<0 & \text { if } m<\frac{\alpha \delta}{n^{*}+\delta} \\
>0 & \text { if } m>\frac{\alpha \delta}{n^{*}+\delta}
\end{array}\right.
$$

The above analysis allows us to establish the following proposition:

Proposition 1. (i) In response to drastic cuts of import tariffs in China, all Chinese firms reduce their export product scope.

(ii) In response to tariff cuts by the foreign country, Chinese firms with efficient management in production and sales will expand their export product scope whereas those with inefficient management in production and sales will reduce their export product scope.

Intuition. The conditions in (18) do not depend on $c$.

Focusing on foreign tariffs, the proposition says that it is the management cost, rather than production cost, that determines the response of a firm. This prediction is consistent with the empirical finding that high productivity firms expand export product scope because usually a very efficient firm is both productive in production and efficient in management. But the proposition says that a firm with high production productivity but low management efficiency will reduce its export product scope.

\subsection{Long-run Equilibrium}

We now examine whether the main results, especially Proposition 1, still hold under general equilibrium in which the number of Chinese firms and that of foreign firms are endogenously determined.

Suppose that there is a cost of entry to the industry by a firm in any country, denoted by $f$. The possible effect of allowing for free entry: lowering Chinese tariff will induce more foreign firm's entry and reduce the number of Chinese firms. This is going to affect 
the total number of firms and products, $M$. The question is whether $M$ will be larger or smaller than the case of fixed number. My guess is $M$ will go up because the market is more competitive (reducing tariff), that is, the increasing of foreign firms is higher than the exit of Chinese firms. If this is correct, then it is more likely to result in Chinese firms reducing export product scope.

By the same reason, when the foreign tariff drops, more Chinese firms enter, and some foreign firms exit. The new entry must be higher than the exit. This will raise $M^{*}$, which make it more likely to reduce export product scope.

\section{[TO BE CONTINUED]}

\section{Empirical Analysis}

In this section, we first introduce our empirical specification, then we construct the measures for the key variables in the estimations, and finally we describe the data.

\subsection{Estimation Framework and Measures}

A firm may produce multiple and differentiated products, called a firm's total product scope, or (product) extensive margin. A firm may export a set (or all) of its products, which is called the export product scope, or export (product) extensive margin. The focus of the present study is on the effects of trade liberalization on individual firms' export product scope. The type of trade liberalization we consider is tariffs reduction. There are two groups of tariffs that potentially affect a Chinese firm's export product scope. On the one hand, when the firm sells its products in the domestic (Chinese) market, it faces import competition. The home country's import tariffs affect the domestic market competition and so the firm's profit from the market, which in turn affects its optimal total product scope. As the firm adjusts its total product scope in response to home country's tariff changes, its export product scope may also change. We call the home country's tariff the home tariff, denoted by HT. On the other hand, when the firm sells to the foreign 
markets, its export profit are affected by the foreign countries' import tariffs, which we call the foreign tariff, denoted by FT. Consequently, the firm's export product scope will be affected. While a country has many tariff lines, it is clear that tariffs that are not relevant to a firm may not have strong impact on the firm's export product scope. Accordingly, we will construct firm-specific tariff in order to better gauge the effects of tariff changes on firms' export product scope.

In addition to tariffs, a firm's productivity level is also an important factor which affects its export product scope (see Qiu and Zhou, 2012). Therefore, we establish the following empirical equation

$$
S_{i t}=\beta_{0}+\beta_{1} T F P_{i t}+\beta_{2} H T_{i t}+\beta_{3} F T_{i t}+\boldsymbol{\theta} \mathbf{\Psi}_{i t}+\epsilon_{i t}
$$

where $S_{i t}$ is firm $i$ 's export product scope, $T F P_{i t}$ firm $i$ ' total factor productivity, $H T_{i t}$ the home (Chinese) tariff level firm $i$ faces, and $F T_{i t}$ the foreign tariff level firm $i$ faces, all in year $t$. In addition, $\boldsymbol{\Psi}_{i t}$ denotes a vector of control variables including firm $i$ 's export market size (foreign countries' GDP), ownership type (state-owned enterprise, multinational firm, or other), and trade mode (processing trade or ordinary trade).

We next turn to describing the construction of firm-specific tariffs. For home tariffs, suppose that firm $i$ produces a set of products, $S_{i}$, for the domestic market. The firm's profit will be affected directly by all tariff lines in its product set, among which a tariff line will have a greater effect if the firm has a larger share of the corresponding product in its total domestic sales. This suggests that the firm-specific tariff should be the average of all relevant tariffs weighted by the share of each product's sales. Unfortunately, data on product-level domestic sales are not available. Alternatively, we adopt a less satisfactory approach by using the share of a firm's export to proxy the share of its domestic sales. Specifically, we introduce the following measure as firm $i$ 's home tariff:

$$
H T_{i t}=\sum_{k \in E_{i t}}\left(\frac{X_{i t}^{k}}{\sum_{k \in E_{i t}} X_{i t}^{k}}\right) \tau_{t}^{k},
$$


where $E_{i t}$ is the set of firm $i$ 's export products, $X_{i t}^{k}$ is the export sales of product $k$ by firm $i$, and $\tau_{t}^{k}$ is the home country's ad valorem tariff on product $k$, all year $t$. Some discussions on this measure are in order. First, the home tariff on a product which is produced by a firm for the domestic market only does not show up in $H T_{i t}$. This is in fact desirable because our left-hand-side variable is a firm's export product scope and it is very unlikely that tariffs on other products will affect these products' profits. Second, $H T_{i t}$ cannot capture the competition effects either for pure domestic firms that do not have any exports or pure exporting firms that completely export their products. We hence drop these both types of firms in all estimates.

Third, $H T_{i t}$ does not include tariffs on other products which the firm does not produce. There are two concerns related to this observation. On the one hand, when tariffs on a firm's competing products change, the firm's existing products' profits and potential products' profitability are affected, which may change the firm's decision on its product margin, i.e., shrinking existing product lines or introducing new products. To capture this effect, our regressions begin from using an industry-wide, as opposed to firm-specific, tariff to replace $H T_{i t}$. On the other hand, $H T_{i t}$ ignores tariffs on intermediate goods. Obviously, changes in the intermediate goods' tariffs will affect the final goods' profits, which then affect a firm's decision on the number of its final goods. However, it is the objective of the present study to analyze the effects of trade liberalization that impacts the final goods market directly, that is, the competition effects. Still, for the sake of completeness, we control for the cost effects associated with tariffs changes on intermediate goods as a robustness check.

The construction of firm-specific foreign tariffs is more complicated than home tariffs because many firms not only export multiple products, but also export them to multiple countries, with different subsets of products to different countries. The measure must capture the relative importance of different foreign country's tariffs on a Chinese firm's 
export. To this end, we propose the following measure for $F T_{i t}$ :

$$
F T_{i t}=\sum_{k \in E_{i t}}\left[\frac{X_{i t}^{k}}{\sum_{k \in E_{i t}} X_{i t}^{k}} \sum_{c \in C_{i t}}\left(\frac{X_{i t}^{k c}}{X_{i t}^{k}}\right) \tau_{t}^{k c}\right],
$$

where $\tau_{t}^{k c}$ is product $k$ 's ad valorem tariff imposed by country $c, X_{i t}^{k c}$ is the value of firm $i$ 's export of product $k$ to country $c$, and $X_{i t}^{k}=\sum_{c \in C} X_{i k t}^{c}$, all in year $t$. The ratio $X_{i t}^{k c} / X_{i t}^{k}$ represents the share of firm $i$ 's product $k$ exported to country $c$, which captures the relative importance of $\tau_{t}^{k c}$ in affecting firm $i$ 's product $k$ export. Thus, $\sum_{c \in C_{i t}}\left(\frac{X_{i t}^{k c}}{X_{i t}^{k}}\right) \tau_{t}^{k c}$ is the weighted average of foreign tariffs on product $k$ for firm $i$.

Finally, we turn to $T F P_{i t}$. While there are many ways of measuring a firm's TFP, or productivity, we adopt the Olley-Pakes (1996) approach to estimate each Chinese firm's TFP (refer to TFP1). ${ }^{7}$ To better reflect China's reality, we make some modifications to the standard Olley-Pakes approach. First, following Brandt et al. (2012) and Feenstra et al. (2013), we use deflated output and input prices at the firm-product level to measure TFP. Second, we use a firm's real capital depreciation to construct its real investment (the perpetual inventory method). ${ }^{8}$ Third, we consider the effect of China's WTO accession in 2001 and firms' processing behavior in the TFP realization. Appendix C provides a detailed description of our augmented Olley-Pakes TFP measures.

\footnotetext{
${ }^{7}$ The Levinsohn and Petrin (2003) approach is also popular in the literature to construct TFP in which materials (i.e., intermediate inputs) are used as a proxy variable. As argued by Yu (2011), this approach is appropriate for firms in countries not using a large amount of imported intermediate inputs, but not appropriate for China as Chinese firms substantially rely on imported intermediate inputs, which have prices that are significantly different from those of domestic intermediate inputs (Helpern et al., 2011).

${ }^{8}$ Since the firm-level dataset only provides the book value of the firm's capital stock, we need to obtain the original value of the firm's capital stock for TFP estimation. To do so, we adopt the following expression $A_{t}=A_{o} \Pi_{s=o}^{t}\left(1+r_{s}\right)$ where $A_{t}$ is the book value of the firm's capital stock in year $t, A_{o}$ is the original value of the firm's capital stock when it was purchased in year $o, r_{s}$ is the estimated province-industry-level growth rate of nominal capital stock in year $s$ obtained from Brandt et al. (2012). As $A_{t}$ and $r_{s}$ are known for each firm, the firm's original nominal book value can be traced out accordingly. There are around $40 \%$ observations missing investment data. However, this is not a problem since our estimation results are not changed by using other measures of TFP, which are not reported in the text to save space but available upon request.
} 


\subsection{Data and Summary Statistics}

Regression (19) and construction of HT, FT and TFP require extensive information of all variables. We will make use of the following three highly disaggregate panel datasets: product-level tariff data of each country, firm-level production data, and firm and productlevel trade data.

First, tariffs. The WTO official webpage provides tariffs at HS six-digit level from all WTO member countries/regions. ${ }^{9}$ The following tariff data for each product category are all available: number of ad valorem (AV) duties and non-AV duties; average, minimum, and maximum AV duties, respectively; percentage of duty free; and the bound duty. For the purpose of our analysis, the average AV duty is the most suitable one and so is included in our dataset.

Second, firm production data. China's National Bureau of Statistics maintains a dataset based on the annual survey of large manufacturing enterprises in China. This dataset, called Chinese Manufacturing Enterprises (CME) dataset includes two types of manufacturing firms, which include state-owned enterprises (SOE), both small and large, and non-SOEs whose annual sales are more than five million $R M B$, with about 162,885 firms in the year 2000 and 301,961 in 2006. ${ }^{10}$ It contains information of more than 100 financial variables from each firm's accounting statement. Although this data set contains rich information, there are obvious omissions and errors. As in Feenstra et al. (2013), we clean the dataset as follows. We drop the observations (i.e., firms) if the key financial variables (such as total assets, net value of fixed assets, sales, and gross value of industrial output) are missing, or the number of employees are not higher than $8 .{ }^{11}$ We also

\footnotetext{
${ }^{9}$ Data can be accessed via http://tariffdata.wto.org/ReportersAndProducts.aspx. Note that TRAINS data generally suffer from missing values problems, particularly regarding the tariffs imposed by other countries for Chinese exports. The product-destination-year combinations that have missing tariffs are hence dropped.

${ }^{10}$ In fact, the aggregate data for the manufacturing sector in the annual China's Statistical Yearbook are compiled from the CEM dataset.

${ }^{11}$ The reason of chosing eight workers as a threshold is that firms with less than eight workers fall under
} 
delete the following observations according to the basic rules of the Generally Accepted Accounting Principles: (i) liquid assets are higher than total assets, (ii) total fixed assets are larger than total assets, (iii) the net value of fixed assets is larger than total assets, (4) the firm's identification number is missing, or (5) there is an invalid established time. Third, export data. China's Customs maintains a highly disaggregate trade database which records each transaction of international trade. It contains a large variety of information about each trading firm including each exporting product's price, quantity, value, and destination. Product information is available at the HS eight-digit level. We use only part of this information to calculate each Chinese firm's export product scope. It is observed that some firms export products from different industries. As our focus is on within industry multiproduct analysis, we assign a firm to an industry at HS 2-digit level in which the firm has most number of products. We drop firms out from the sample if they include other industries' products. ${ }^{12}$

Our study requires us to merge the China Customs dataset and the CME dataset. As these two datasets use completely different firm-identification systems, we have to find various ways to do the matching. By using firms' (Chinese) names, zip codes and telephone numbers, we are able to match 76,946 firms. ${ }^{13}$ They account for more than $40 \%$ of manufacturing firms reported in the CME dataset and around $70 \%$ of the export value reported in the customs dataset. This representation is quite comparable to Bernard et al. (2009) for the US data and Ma et al. (2011) for the Chinese data. ${ }^{14}$

Data summary statistics are provided in Table 1. Export product scopes have a very

different legal regime, as mentioned in Brandt et al. (2012). We adopt this criterion for the consideration that a very small company may not have a good accounting system/report. However, our results are not sensitive to this critical level.

${ }^{12} \mathrm{An}$ alternative way to deal with this issue is to drop other industries' products when calculating the firm's export product scope. Our estimation results are not changed by using such an alternative approach. Such estimation results are not reported to save space, but available upon request.

${ }^{13}$ The same matching is also done in Yu and Tian (2012).

${ }^{14}$ Our merged dataset has higher mean of sales than the full-sample NBS dataset, indicating that larger firms are more likely to be matched. 
large variation: The minimum of export product scope is one (i.e., a single product) whereas the maximum is up to 527 products. Around $86 \%$ of Chinese firms (in our merged dataset) export more than a single product during 2000-2006 whereas the rest $14 \%$ export a single product. Moreover, around a half of the firms export less than five products, $75 \%$ of the firms export less than nine products, and only $1 \%$ of the firms export more than 50 products. The average home tariffs is slightly higher than the average foreign tariffs, suggesting China's average import tariffs are close to the average level of the rest of the world after China's accession to the WTO. ${ }^{15}$

\section{[Insert Table 1 Here]}

\section{Estimates}

\subsection{Benchmark Estimates}

We start our regressions by using industry-level home tariffs for two reasons. First, this can ensure that our firm-specific tariffs measure would not generate qualitative difference from the traditional industry tariffs measures. Second, this approach is justified by the following hypothesis: A firm adjusts its product scope not only responding to trade liberalization in its existing tariff lines, but also responding to trade liberalization in other tariff lines. The reason is not difficult to see. Suppose that a firm produces products $\mathrm{x}$ and $\mathrm{y}$ and there is a large reduction in product z's tariff. Then producing $\mathrm{z}$ becomes profitable for the firm. However, if the firm produces z, it may dilute its profit from existing products (e.g., drawing resources away from production of existing products). Thus, the total product scope may go up or down, depending on how much the existing products' profits are affected.

Estimates in Table 2 start from a pooling OLS regression by using simple-average

\footnotetext{
${ }^{15}$ Note that the maxium foreign tariffs is up to 960 percent since some China's trading partners (e.g., Egypt) still impose extremely high tariffs in some industries. We hence drop the top $1 \%$ outlier from the sample, yielding a maximumn foreign tariffs with a reasonable number (41.5\%). Including such outliers does not change our estimation results at all.
} 
industry home tariffs at HS 2-digit level whereas abstracting away foreign tariffs and input tariffs. Industry home tariffs are found to be positively associated with firm's export scope, suggesting that firms reduce their export scope in response to home tariffs cut. Meanwhile, our data show a clear pattern that most firms export a small number of products while a very small fraction of firms export a very large number of products. This suggests that the dependent variable does not follow the normal distribution, which is assumed when using the OLS approach. Thus, the OLS result reported in column (1) of Table 2 may be biased.

The count-data estimates would be more reliable because the product scopes are nonnegative integers (Cameron and Trivedi, 2005). Since Poisson distribution is the most popular discrete distribution to capture the characteristics of various count data, we first derive the Poisson estimate (with a clustered robust standard error). Specifically, the dependent variable is assumed to have a probability function $f(s, \mu)=\frac{\exp (-\mu) \mu^{s}}{s !}$, where $\mu=\exp \left(\mathbf{X}^{\prime} \boldsymbol{\beta}\right)$ and $\mathbf{X}$ denotes the vector of independent variables. We report the regression results in column (2) of Table 2 . It turns out that the main results obtained from OLS remain valid. In particular, both the home tariffs and foreign tariffs have positive and significant effects on export product scopes

Although Poisson distribution is a popular approach, it may not be the best representation of our sample distribution. If our sample follows a Poisson distribution, we should expect that the mean and variance of firm's export product scope are identical and equal to $\mu$. However, our data reveals that the variance of the sample $(\operatorname{var}(s)=96.9)$ is around 15 times larger than its mean $(\bar{s}=6.5)$, indicating that Poisson distribution is not a good distribution to represent our data. Moreover, the test of the goodness of fit for the Poisson model reports an extremely large $\chi^{2}$ value $(607,445)$, which double-confirms the inappropriateness of Poisson distribution for our dependent variable.

We then appeal to the negative binomial distribution because it allows the sample to exhibit a pattern of over-dispersion. Note that the probability density function of negative bi- 
nomial distribution has the following form: $f(s, \mu)=\frac{\Gamma\left(\alpha^{-1} \mu+s\right)}{\Gamma\left(\alpha^{-1} \mu\right) \Gamma(s+1)}\left(\frac{\alpha^{-1} \mu}{\alpha^{-1} \mu+\mu}\right)^{\frac{1}{\alpha}}\left(\frac{\mu}{\alpha^{-1} \mu+\mu}\right)^{s}$, where $\mu=\exp \left(\mathbf{X}^{\prime} \boldsymbol{\beta}\right)$ as in the Poisson distribution above and $\Gamma(\cdot)$ is the Gamma function. Here the mean of the scope is $\bar{s}$ whereas the variance can be over dispersed to $(1+\alpha \bar{s}) \bar{s}$. In fact, when drawing a graph based on the proportion of firms with different export product scope (see Figure 1), we notice that the negative binomial distribution approximates the observed distribution much better than the Poisson distribution. Since most firms have a scope less than 10, we assume 10 as the maximum value of the discrete level. ${ }^{16} \mathrm{We}$ report the regression results in column (3) of Table 2 . We find that the over-dispersion parameter $\alpha$ generated by the likelihood ratio test is significantly different from zero (we obtain $\alpha=.660$ from the regression), indicating that negative binomial distribution is a good assumption. ${ }^{17}$ Importantly, the coefficient of home tariffs is positive and statistically significant. Furthermore, some other time-variant variables such as exchange rate may affect trade and so firms' optimal export product scopes. We include year-specific fixed effects in the regressions. Meanwhile, we include firm-specific fixed effects to control for the effects of firm-variant variables such as unobservable managerial ability. ${ }^{18}$ The negative binomial estimates are reported in column (4). The coefficient of home tariffs, again, is positive and highly significant. Note that when year fixed effect is introduced, another control variable, China's GDP, will be dropped automatically.

We then include foreign tariffs, $F T_{i t}$, in column (5) and find its coefficient positive and significant, suggesting that home firms reduce their export scope in response to foreign tariffs cut. Finally, trade liberalization in output market affects competition and so firms respond by changing their product scope. However, trade liberalization in input market affects costs and firms may also adjust their product scope. To control for the possible

\footnotetext{
${ }^{16}$ Note that changing such a maximum number does not change our estimation results.

${ }^{17}$ We have also performed the regression based on gamma distribution, which generates very similar results as the negative binomial distribution. Such results are not reported in the table to save space, but available upon request.

${ }^{18}$ Note that firm-specific fixed effects in the negative binomial model apply to the distribution of the dispersion parameter (Hardin and Hilbe, 2003).
} 
cost effects, we include the "home input tariffs" variable. It is difficult to construct a precise firm specific "home input tariffs" variable especially for China as not all firms facing the same effective tariff rates even if they import the same inputs. As it is well known, processing imports are duty-free in China. Given that a firm could engage in both processing imports $(P)$ and non-processing imports $(O)$, we adopt the following index of firm-specific input tariffs $\left(F I T_{i t}\right)$ suggested by Yu (2011) as our "home input tariffs" for firm $i$ :

$$
F I T_{i t}=\sum_{k \in O} \frac{m_{i, \text { initial_year }}^{k}}{\sum_{k \in M} m_{i, \text { initial_year }}^{k}} \tau_{t}^{k},
$$

where $m_{i, \text { initial_year }}^{k}$ is firm $i$ 's imports of product $k$ in the first year the firm appears in the sample. Note that $O \cup P=M$ where $M$ is the set of the firm's total imports. The set of processing imports does not appear in Eq. (22) because processing imports are dutyfree. The firm's input tariffs are constructed by using time-invariant weights to avoid the well-known endogeneity of weighted tariffs: imports are negatively associated with tariffs. For products with prohibitive tariffs, their imports and the associated import share would be zero. Accordingly, if the import weight is measured in the current period, the measure of firm tariffs would face a downward bias. Therefore, following Topalova and Khandelwal (2011), we measure the import weight for each product using data for the firm's first year in the sample.

The last column of Table 2 reports the negative binomial estimates when "home input tariffs" is included as a control variable. It shows that trade liberalization in intermediate goods imports tends to lower export product scope. The inclusion of such a control variable would not alter the effects and significance of the two key variables, that is, home tariffs and foreign tariffs.

We now turn to other control variables. All estimates in Table 2 show that more productive firms have a larger export product scope. This finding is consistent with the 
prediction of all theoretical studies on multiproduct firms. It is also found by Eaton et al. (2011) from French data. Like in all gravity models of international trade, GDP of both the importing and exporting countries have a positive effects on the flows of trade between the trading partners. In our regression based on all three distributions, we find that both increases in China's GDP and foreign countries' GDP raise Chinese firms' export product scopes. To better capture the effects of foreign countries' GDP, we construct the firm-specific GDP using the share of a firm's export to each country as the weight of the corresponding importing country's GDP. Once controlling for firm-specific and yearspecific fixed effects, a firm's capital-labor ratio has a negative effect on its export product scope. Other things equal, state-owned enterprises (SOEs) have larger export product scope than non-SOEs; and firms engaging in processing trade have smaller export product scopes than other firms only engaging in ordinary trade. ${ }^{19}$

[Table 2 Here]

We replace industry-level home tariffs with firm-specific home tariffs as measured by Eq. (20) in negative binomial regressions of Table 3. As shown in column (1), the coefficient of firm-specific home tariffs is still positive and significant, suggesting that our findings are qualitatively robust by using different measure of home tariffs. Equally importantly, the coefficient of home tariffs in column (1) is smaller than its counterpart in the last column of Table 2, indicating that using industry tariffs would create a upward estimation bias. However, one may concern that firm-specific home tariffs would not be impotent to capture the roles of pure domestic firms and pure exporting firms. To rule out such cases, we first drop pure domestic firms in column (2), pure exporting firms in column (3), and both in column (4). Our estimation results are still robust in all such experiments: the coefficients of home tariffs and foreign tariffs are positive and statis-

\footnotetext{
${ }^{19}$ Note that some firms change their types of ownership and shipment mode (i.e., processing or ordinary exports). Hence, SOE indicator, foreign indicator, and processing indicator are not dropped from the fixed-effects estimates. We do not report the transitional probability matrixes in the text to save space, but available upon request.
} 
tically significant. When there is domestic trade liberalization, home firms reduce their export product scope; in response to foreign countries' trade liberalization, home firms also reduce their export product scope..$^{20}$

\section{[Table 3 Here]}

\subsection{Estimates Using Alternative Measures}

When we construct the two key variables, we use the current year's tariffs and the weighted based on current year's production value. There are two potential problems. First, firms may not have sufficient time to adjust to the tariff changes in the same year. Second, as we use the current year's trade value as the weight to construct the firm specific tariffs, it may lead to an endogeneity problem. For example, if a firm drops an variety $\mathrm{x}$ this year due to tariff changes, variety x's tariff will not show up in the tariffs defined previously, which is not correct. We now examine whether our main results (Table 3) are sensitive to our tariff measures.

There are many ways to tackle the above problems. As it is common in the literature, one way to avoid the endogeneity problem, and at the same time to address the first problem, is to use a previous year's tariffs to replace the current year's tariffs. This is indicated by "home tariffs (lag)" and "foreign tariffs (lag)", respectively. In particular, we construct the following measure for our firm-specific home tariffs:

$$
H T_{i t}^{A l t}=\sum_{k}\left(\frac{v_{i t-1}^{k}}{\sum_{k} v_{i t-1}^{k}}\right) \tau_{t}^{k},
$$

where the weight of domestic sales is from the previous year's sales (one-period lag in weight). The fixed-effects estimates in column (1) of Table 4 indicate that both the home tariffs and foreign tariffs are still positive and significant. We construct the foreign tariffs

\footnotetext{
${ }^{20}$ One potential problem is that trade liberalization in both China and foreign countries take place at the same time due to the continuous effort of the WTO, which suggesting a possible correlation between $H T$ and FT. We check this and find that this is not a worry given that the simple correlation between the two variable is 0.01 .
} 
following the same approach and rerun the regression in column (2). In particular, the alternative firm-specific foreign tariffs $\left(F T_{i t}^{A l t}\right)$ is measured as follows:

$$
F T_{i t}^{A l t}=\sum_{k \in E_{i t}}\left[\frac{X_{i t-1}^{k}}{\sum_{k \in E_{i t-1}} X_{i t}^{k}} \sum_{c \in C_{i t}}\left(\frac{X_{i t-1}^{k c}}{X_{i t-1}^{k}}\right) \tau_{t}^{k c}\right] .
$$

The results are basically the same as those in column (1).

As argued previously, a firm may respond to the previous year's tariff changes, but not the current year's tariff changes. This suggests that we should use a different tariff measure like the following: $\sum_{k}\left(v_{i t-2}^{k} / \sum_{k} v_{i t-2}^{k}\right) \tau_{t-1}^{k}$. This is a measure using tariffs of the previous year and production of the the year before for the weights. Using these home and foreign tariffs in the negative binomial regression, we find that the qualitative results remain unchanged, as reported in column (4). The last column adds the alternative firm-specific foreign tariffs $\left(F T_{i t}^{A l t}\right)$ in the regression and yields the same results.

[Table 4 Here]

\subsection{Effect by Managerial Efficiency}

Our theoretical model predicts that the effects of foreign tariffs reduction on export scope differ by managerial efficiency. High (low) management cost firms reduce (increase) their scope in response to foreign tariff cut regardless of their production productivity.

To this end, Table 5 first introduces two indicators of managerial efficiency in the regression: low managerial efficiency (i.e., high overhead expenses) and high managerial efficiency (i.e., low overhead expenses) indicators. Firm's overhead expenses is used to proxy its managerial efficiency following the conventional measures in accounting. A high overhead indicator takes one if a firm's overhead expenses (in logarithm) is higher than the top $25^{\text {th }}$ quantile of all firms' overhead expenses (in logarithm) and zero otherwise. Analogously, a low overhead indicator takes one if a firm's overhead expenses (in logarithm) is lower than the bottom $25^{\text {th }}$ quantile of all firms' overhead expenses (in logarithm) and 
zero otherwise. All firms are accordingly separated into three groups: high, low, and middle efficiency groups.

As suggested by our theoretical model, production productivity is also an important factor to determine firm's export scope. We hence shall include it in the regressions in Table 5. However, an empirical identification challenge occurs. The conventional TFP measure is a "Solow" residual which also takes firm's managerial efficiency into account. We need to separate firm's true production productivity from its regular TFP measure so that both true production productivity and managerial efficiency can be identified. For this purpose, inspired by Feenstra et al. (2013), we construct an ex-ante productivity measure (TFP2) which differs from the standard ex-post productivity measure (TFP1) but is closer to the framework of Melitz and Ottaviano (2008). To motivate this from the Olley-Pakes (1996) framework, consider a standard Cobb-Douglas gross production function:

$$
\ln Y_{i t}=\alpha_{k} \ln K_{i t}+\alpha_{l} \ln L_{i t}+\alpha_{m} \ln M_{i t}+x_{i t}+\varepsilon_{i t},
$$

where $Y_{i t}, K_{i t}, L_{i t}, M_{i t}$ and $x_{i t}$ are firm $i$ 's sales, capital, labor, intermediate inputs and productivity in year $t$, respectively. ${ }^{21}$ The conventional measure of productivity is to take the difference between log output and log factor inputs times their estimated coefficients:

$$
T F P 1_{i t} \equiv x_{i t}=\ln Y_{i t}-\hat{\alpha}_{k} \ln K_{i t}-\hat{\alpha}_{l} \ln L_{i t}-\hat{\alpha}_{m} \ln M_{i t} .
$$

Under this approach, firm productivity (TFP1) is clearly correlated with the ex-post productivity shock $\left(\varepsilon_{j t}\right)$ such as managerial efficiency.

As suggested by Feenstra et al. (2013), we can construct a new measure of productivity. Suppose that investment $V_{i t}$ in the Olley-Pakes depends on the anticipated productivity $T F P 2_{i t}$ of the firm according to a functional relation: $V_{i t}=g_{1}\left(x_{i t}, \ln K_{i t}, E X_{i t}, P E_{i t}, W T O_{t}\right)$ where $E X_{i t}\left(P E_{i t}\right)$ is the export (processing export) indicator to measure whether firm $i$ exports (engages in processing exports) in year $t$, and $W T O_{t}$ is an indicator that equals

\footnotetext{
${ }^{21}$ Note that Feenstra et al. (2013) work on a value-added production function instead.
} 
one if the WTO agreement has occurred after 2001 and zero before that. Inverting this relation, the anticipated productivity can be obtained as:

$$
T F P 2_{i t}=g_{1}^{-1}\left(V_{i t}, \ln K_{i t}, E X_{i t}, P E_{i t}, W T O_{t}\right)
$$

with a careful discussion in Appendix C. In this way, the measure of ex-ante productivity (TFP2), by construction, is independent of other unspecified factors such as firm's managerial efficiency inclusive in the error term $\varepsilon_{j t}$. Appendix Table A2 provides firm's TFP1 and TFP2 in each estimates associated with the coefficients of labor, capital, and materials.

As shown in Column (1) of Table 5, high productivity firms have more export scopes. Since our main interest is to see how firms with different managerial efficiency will adjust their export product scope in response to foreign trade liberalization, we interact foreign tariffs $\left(F T_{i t}\right)$ with both high and low managerial efficiency indicators. Once again, we find that both home tariffs and foreign tariffs variables have positive and statistically significant coefficients as before. More importantly, the interaction between foreign tariffs and the high managerial efficiency (i.e., low overhead) dummy is negative and significant, with a much larger economic magnitude than the own coefficient of foreign tariffs, indicating that the effect of foreign tariffs on export scope is negative (e.g., .003 - .774 $<0$ in Column (1)). Thus, foreign tariffs reduction increases export scope for high managerial efficiency firms. By contrast, the coefficients of the interaction between foreign tariffs and the low managerial efficiency (i.e., high overhead) indicator are positive and significant, suggesting that foreign tariffs reduction reduces export scope for low managerial efficiency firms. This observation also applies to the middle managerial efficiency firms. Column (2) controls for firm's input tariffs as measured by Eq. (22) and yields similar results to those in Column (1). One may worry that whether our results are sensitive to the measure of firm-specific home tariffs measure. We hence replace firm-specific home tariffs with industry-level home tariffs in Columns (3)-(4) and find that all results remain robust. 


\section{[Table 5 Here]}

Thus far, we have seen rich evidence that both home tariffs cut and foreign tariffs cut reduce firm's export scope, respectively. More interestingly, high (low) management cost firms reduce (increase) their scope in response to foreign tariff cut. For the latter finding, one may be curious whether such a finding is driven by firm's size given that large firms usually have more overhead expenses. To address such a possible concern, we use firm's overhead expense relative to its size (measured by number of employees) as a measure of firm's managerial cost. That is, we use per-capita overhead expense in Table 6 to construct high and low overhead indicators. Once again, we see that the net impact of foreign tariffs cut on export scope is negative for firms with low overhead expenses but is positive for firms with high overall expenses. This suggests that low (high) managerial efficiency firms reduce (increase) their scope in response to foreign tariffs reduction.

[Table 6 Here]

\section{Concluding Remarks}

$[\mathrm{TBA}]$ 


\section{References}

[1] Ackerberg., Daniel, Kevin Caves, and Garth Frazer (2006), "Structural Identification of Production Functions," UCLA mimeo.

[2] Bernard, Andrew, Jonathan Eaton, Bradford Jensen, and Samuel Kortum (2004), "Plants and Productivity in International Trade," American Economic Review, 93(4), pp. 1268-1290.

[3] Bernard, Andrew, Bradford Jensen, and Peter Scott (2009), "Importers, Exporters, and Multinationals: A Portrait of Firms in the U.S. that Trade Goods," in Producer Dynamics: New Evidence from Micro Data, edited by Timothy Dunne, Bradford Jensen, and Mark Roberts, University of Chicago Press.

[4] Bernard, Andrew, Stephen J. Redding, and Peter K. Schott (2010), "MultipleProduct Firms and Product Switching," American Economic Review, 100(1), pp. 70-97.

[5] Bernard, Andrew, Stephen J. Redding, and Peter K. Schott (2011), "MultipleProduct Firms and Trade Liberalization," Quarterly Journal of Economics, 126(1), pp.70-97.

[6] Blundell, Richard and Stepen Bond (1998), "Initial Conditions and Moment Restrictions in Dynamic Panel Data Models," Journal of Econometrics 87, pp. 11-143.

[7] Brandt, Loren, Johannes Van Biesebroeck, and Yifan Zhang (2012), "Creative Accounting or Creative Destruction? Firm-Level Productivity Growth in Chinese Manufacturing," Journal of Development Economics 97, pp. 339-331.

[8] Bustos, Paula (2011), "Trade Liberalization, Exports and Technology Upgrading: Evidence on the Impact of MERCOSUR on Argentinean Firms," American Economic Review, 101(1), pp. 304-340.

[9] Cameron, Colin and Pravin Trivedi (2005), Microeconometrics: Methods and Applications, Cambridge University Press.

[10] Dhingra, Swati (2009), "Trading Away Wide Brands for Cheap Brands," miemo, London School of Economics.

[11] Eaton Jonathan, Samuel Kortum, and Francis Kramarz (2011), "An Anatomy of International Trade: Evidence from French Firms," Econometrica, forthcoming.

[12] Feenstra, Robert and Gordon Hanson (2005), "Ownership and Control in Outsourcing to China: Estimating the Property-Rights Theory of the Firm," Quarterly Journal of Economics, 120(2), pp. 729-762.

[13] Feenstra, Robert, Zhiyuan Li, and Miaojie Yu (2013), "Exports and Credit Constraints under Incomplete Information: Theory and Applications to China," Review of Economics and Statistics, forthcoming.

[14] Ge Ying, Lai Huiwen, Susan Zhu (2011), "Intermediates Import and Gains from Trade Liberalization", Miemo.

[15] Hausman J. A. B. H. Hall, and Z. Griliches (1984), "Econometric Models for Count Data with an Application to the Paterns-R and D Relationship," Econometrica 52, pp. 909-938. 
[16] Hardin, J.W. and J.M. Hilbe (2003), Generalized Estimating Equations, Boca Raton, FL: Chapman \& Hall/CRC.

[17] Helpern, Laszlo, Miklos Koren, and Adam Szeidl (2010), "Imported Inputs and Productivity," miemo, University of California, Berkeley.

[18] Levinsohn, James and Amil Petrin (2003), "Estimating Production Functions Using Inputs to Control for Unobservable," Review of Economic Studies 70(2), pp. 317-341.

[19] Lin, Yifu, Justin (2012), New Structural Economics: A Framework for Rethinking Development and Policy, The World Bank.

[20] Ma, Y., Tang, H., and Y. Zhang (2011) "Factor Intensity, Product Switching, and Productivity: Evidence from Chinese Exporters," CENTRO STUDI LUCA D'AGLIANO development studies, working papers No. 324.

[21] Olley, Steven and Ariel Pakes (1996), "The Dynamics of Productivity in the Telecommunications Equipment Industry," Econometrica 64(6), pp. 1263-1297.

[22] Qiu, D. Larry and Wen Zhou (2012), "Multiproduct Firms and Scope Adjustment in Globalization," Journal of International Economics, forthcoming.

[23] Melitz, Marc (2003), "The Impact of Trade on Intra-industry Reallocations and Aggregate Industry Productivity," Econometrica 71(6), pp. 1695-1725.

[24] Topalova, Petia and Amit Khandelwal (2011), "Trade Liberalization and Firm Productivity: The Case of India," Review of Economics and Statistics 93(3), pp. 9951009.

[25] Yu, Miaojie (2011), "Processing Trade, Firm Productivity, and Tariff Reductions: Evidence from Chinese Products," Available at SSRN: http://ssrn.com/abstract $=1734720$.

[26] Yu, Miaojie and Wei Tian (2012), "China's Processing Trade: A Firm-Level Analysis," in Huw McMay and Ligang Song (eds.) Rebalancing and Sustaining Growth in China, Australian National University E-press, pp. 111-48. 
Table 1: Summary Statistics

\begin{tabular}{lllll}
\hline \hline Variable & Mean & Std. Dev. & Min & Max \\
\hline Year & & & 2000 & 2006 \\
Export Product Scope & 6.49 & 9.84 & 1 & 527 \\
Annual Sales (RMB1,000) & 150,053 & $1,061,312$ & 5,000 & $1.57 \mathrm{e}+0.8$ \\
Number of Empolyees & 479 & 1,687 & 8 & 157,213 \\
Home Tariffs (Firm Level) & 8.34 & 7.69 & 0 & 65.26 \\
Home Tariffs (Industry Level) & 11.72 & 5.59 & 0 & 58.75 \\
Foreign Tariffs (Firm Level) & 7.38 & 19.22 & 0 & 41.47 \\
Home Input Tariffs (Firm Level) & 2.12 & 3.88 & 0 & 90 \\
Log China's GDP & 28.29 & .265 & 27.81 & 28.62 \\
Log Importers' Weighted GDP & 28.70 & 2.43 & 10.15 & 34.69 \\
Per-capita Overhead Expenses & 277.1 & 668.1 & 0 & 73,581 \\
Log of Overhead Expenses & 6.83 & 2.18 & 0 & 16.66 \\
SOE Indicator & .021 & .141 & 0 & 1 \\
Foreign Indicator & .589 & .491 & 0 & 1 \\
Processing Indicator & .286 & .452 & 0 & 1 \\
\hline
\end{tabular}

Notes: US $\$ 1$ is equivalent to approximately 8.20 during 2000-2006. 
Table 2: Estimates of Tariffs on Scope using Industry Home Tariffs

\begin{tabular}{|c|c|c|c|c|c|c|}
\hline \multirow{2}{*}{$\begin{array}{l}\text { Econometric Methods } \\
\text { Regressand: Export Product Scope }\end{array}$} & \multirow{2}{*}{$\begin{array}{l}\text { OLS } \\
(1)\end{array}$} & \multirow{2}{*}{$\begin{array}{c}\text { Poisson } \\
(2)\end{array}$} & \multicolumn{4}{|c|}{ Negative Binomial } \\
\hline & & & $(3)$ & $(4)$ & $(5)$ & $(6)$ \\
\hline & $.302^{* * *}$ & $.035^{* * *}$ & $.039^{* * *}$ & $.014^{* * *}$ & $.013^{* * *}$ & $.009^{* * *}$ \\
\hline & $(39.14)$ & $(32.34)$ & $(63.22)$ & $(21.53)$ & $(20.86)$ & $(15.40)$ \\
\hline \multirow[t]{2}{*}{ Foreign Tariffs } & & & & & $.007^{* * *}$ & $.003^{* * *}$ \\
\hline & & & & & $(21.07)$ & $(12.44)$ \\
\hline \multirow[t]{2}{*}{ Home Input Tariffs } & & & & & & $.313^{* * *}$ \\
\hline & & & & & & $(4.70)$ \\
\hline \multirow[t]{2}{*}{ Log Firm TFP (TFP1) } & $1.955^{* * *}$ & $.206^{* * *}$ & $.276 * * *$ & $.106^{* * *}$ & $.104^{* * *}$ & $.054^{* * *}$ \\
\hline & $(15.75)$ & $(13.93)$ & $(27.96)$ & $(14.95)$ & $(14.63)$ & $(8.56)$ \\
\hline \multirow[t]{2}{*}{ Log China's GDP } & $1.266^{* * *}$ & $.197^{* * *}$ & $.182^{* * *}$ & & & \\
\hline & $(8.18)$ & $(8.58)$ & $(13.20)$ & & & \\
\hline \multirow[t]{2}{*}{ Log Weighted GDP of Importers } & $1.303^{* * *}$ & $.214^{* * *}$ & $.150 * * *$ & $.127 * * *$ & $.129 * * *$ & $.109 * * *$ \\
\hline & $(64.47)$ & $(44.71)$ & $(133.10)$ & $(89.40)$ & $(90.36)$ & $(77.92)$ \\
\hline \multirow[t]{2}{*}{ Log Capital-Labor Ratio } & $.175^{* * *}$ & $.024^{* * *}$ & $.012^{* * *}$ & $-.011^{* * *}$ & $-.012^{* * *}$ & $-.022^{* * *}$ \\
\hline & $(6.11)$ & $(4.46)$ & $(5.27)$ & $(-4.20)$ & $(-4.43)$ & $(-7.57)$ \\
\hline \multirow[t]{2}{*}{ Foreign Indicator } & $.231^{* * *}$ & .003 & $.055 * * *$ & $.122^{* * *}$ & $.123^{* * *}$ & -0.014 \\
\hline & $(2.92)$ & $(0.16)$ & $(8.47)$ & $(13.04)$ & $(13.05)$ & $(-1.21)$ \\
\hline \multirow[t]{2}{*}{ SOE Indicator } & $.877^{* * *}$ & $.129 * *$ & $.070 * * *$ & $.078^{* * *}$ & $.081^{* * *}$ & 0.032 \\
\hline & $(3.11)$ & $(2.24)$ & $(3.15)$ & $(2.86)$ & $(2.98)$ & $(1.14)$ \\
\hline \multirow[t]{2}{*}{ Processing Indicator } & $-.303^{* * *}$ & $-.073^{* * *}$ & $-.035 * * *$ & $-.023^{* * *}$ & $-.023 * * *$ & $-.052^{* * *}$ \\
\hline & $(-3.94)$ & $(-6.19)$ & $(-5.04)$ & $(-4.24)$ & $(-4.14)$ & $(-12.55)$ \\
\hline ecific Fixed Effects & No & No & No & Yes & Yes & Yes \\
\hline Year-specific Fixed Effects & No & No & No & Yes & Yes & Yes \\
\hline Observations & 96,139 & 96,139 & 96,139 & 96,139 & 96,139 & 53,613 \\
\hline
\end{tabular}

Note: Robust t-values corrected for clustering at the firm level in parentheses. $*(* *)$ indicates significance at the $10(5)$ percent level. 
Table 3: Negative Binomial Estimates of Tariffs on Scope

\begin{tabular}{lcccc}
\hline \hline Regressand: Export Product Scope & $(1)$ & $(2)$ & $(3)$ & $(4)$ \\
\hline Home Tariffs & $.004^{* * *}$ & $.005^{* * *}$ & $.014^{* * *}$ & $.019^{* * *}$ \\
& $(10.49)$ & $(11.61)$ & $(24.91)$ & $(26.13)$ \\
Foreign Tariffs & $.003^{* * *}$ & $.004^{* * *}$ & $.003^{* * *}$ & $.004^{* * *}$ \\
& $(13.38)$ & $(12.35)$ & $(11.45)$ & $(10.38)$ \\
Home Input Tariffs & $.256^{* * *}$ & $.328^{* * *}$ & $.324^{* * *}$ & $.384^{* * *}$ \\
& $(3.83)$ & $(3.98)$ & $(4.65)$ & $(4.06)$ \\
Log Firm TFP (TFP1) & $.053^{* * *}$ & $.065^{* * *}$ & $.066^{* * *}$ & $.097^{* * *}$ \\
& $(8.85)$ & $(8.36)$ & $(9.87)$ & $(9.86)$ \\
Log Weighted GDP of Importers & $.110^{* * *}$ & $.110^{* * *}$ & $.120^{* * *}$ & $.124^{* * *}$ \\
& $(80.07)$ & $(66.40)$ & $(80.21)$ & $(62.65)$ \\
Log Capital-Labor Ratio & $-.026^{* * *}$ & $-.027^{* * *}$ & $-.021^{* * *}$ & $-.018^{* * *}$ \\
& $(-9.32)$ & $(-8.07)$ & $(-6.98)$ & $(-4.67)$ \\
Foreign Indicator & -.006 & $-.034^{* * *}$ & -.009 & $-.039^{* * *}$ \\
& $(-0.50)$ & $(-2.69)$ & $(-0.79)$ & $(-2.84)$ \\
SOE Indicator & $.051^{*}$ & .026 & $.071^{* *}$ & .059 \\
& $(1.83)$ & $(0.77)$ & $(2.57)$ & $(1.64)$ \\
Processing Indicator & $-.053^{* * *}$ & $-.059^{* * *}$ & $-.048^{* * *}$ & $-.056^{* * *}$ \\
& $(-13.26)$ & $(-11.93)$ & $(-11.33)$ & $(-9.44)$ \\
Firm-specific Fixed Effects & Yes & Yes & Yes & Yes \\
Year-specific Fixed Effects & Yes & Yes & Yes & Yes \\
Pure Domestic Firms Dropped & No & Yes & No & Yes \\
Pure Exporting Firms Dropped & No & No & Yes & Yes \\
Prob.> $\chi^{2}$ & .000 & .000 & .000 & .000 \\
Observations & 59,975 & 51,288 & 51,744 & 43,057 \\
\hline & & & &.
\end{tabular}

Note: Robust t-values corrected for clustering at the firm level in parentheses. ${ }^{*}(*)$ indicates significance at the 10(5) percent level. Home tariffs, foreign tariffs, home input tariffs are measured by using Eq. (20), Eq. (21), and Eq. (22) respectively. 
Table 4: Negative Binomial Estimates with Alternative Tariffs Measures

\begin{tabular}{lcccc}
\hline Measure of Home Tariffs & \multicolumn{3}{c}{ One-Lag in Weights } & \multicolumn{2}{c}{$\begin{array}{c}\text { Two-Lag in Weights \& } \\
\text { One-Lag in Tariffs }\end{array}$} \\
\cline { 2 - 5 } Regressand: Export Product Scope & $(1)$ & $(2)$ & $(3)$ & $(4)$ \\
\hline Home Tariffs & $0.010^{* * *}$ & $0.017^{* * *}$ & $0.006^{* * *}$ & $0.006^{* * *}$ \\
& $(14.12)$ & $(15.25)$ & $(14.74)$ & $(9.70)$ \\
Foreign Tariffs & $0.006^{* * *}$ & & $0.006^{* * *}$ & \\
& $(12.36)$ & & $(12.44)$ \\
Foreign Tariffs (One-Lag in Weight) & & $0.004^{* * *}$ & & $0.004^{* * *}$ \\
& & $(6.04)$ & & $(6.57)$ \\
Firm Input Tariffs & $0.003^{* * *}$ & $0.003^{*}$ & $0.003^{* * *}$ & $0.004^{* *}$ \\
& $(3.04)$ & $(1.83)$ & $(2.88)$ & $(2.25)$ \\
Log Firm TFP (TFP1) & $0.107^{* * *}$ & $0.151^{* * *}$ & $0.107^{* * *}$ & $0.155^{* * *}$ \\
& $(9.31)$ & $(7.41)$ & $(9.12)$ & $(7.31)$ \\
Log Weighted GDP of Importers & $0.135^{* * *}$ & $0.143^{* * *}$ & $0.136^{* * *}$ & $0.147^{* * *}$ \\
& $(60.57)$ & $(42.10)$ & $(60.25)$ & $(42.26)$ \\
Foreign Indicator & $-0.039^{* * *}$ & $-0.052^{* * *}$ & $-0.044^{* * *}$ & $-0.063^{* * *}$ \\
& $(-2.61)$ & $(-2.58)$ & $(-2.98)$ & $(-3.15)$ \\
SOE Indicator & 0.043 & 0.023 & 0.037 & 0.018 \\
& $(1.10)$ & $(0.38)$ & $(0.94)$ & $(0.29)$ \\
Processing Indicator & $-0.025^{* * *}$ & $-0.029^{* * *}$ & $-0.024^{* * *}$ & $-0.028^{* *}$ \\
& $(-3.56)$ & $(-2.60)$ & $(-3.41)$ & $(-2.33)$ \\
Firm-specific Fixed Effects & Yes & Yes & Yes & Yes \\
Year-specific Fixed Effects & Yes & Yes & Yes & Yes \\
Prob.> $\chi^{2}$ & .000 & .000 & .000 & .000 \\
Observations & 37,425 & 20,490 & 37,425 & 20,490 \\
\hline
\end{tabular}

Note: Robust $\mathrm{t}$-values corrected for clustering at the firm level in parentheses. *,**,*** indicates significance at the 10,5, and 1 percent level. Pure processing firms are dropped in all columns. Home tariff indices in Columns (1)-(2) are measured as $\sum_{k}\left(\frac{v_{i t-1}^{k}}{\sum_{k} v_{i t-1}^{k}}\right) \tau_{t}^{k}$ whereas home tariff indices in Columns (3)-(4) are measured as $\sum_{k}\left(\frac{v_{i t-2}^{k}}{\sum_{k} v_{i t-2}^{k}}\right) \tau_{t-1}^{k}$. Firm foreign tariffs is measured by Eq. (21) whereas foreign tariffs with one-lag in weight is measured as $\sum_{k \in E_{i t}}\left[\frac{X_{i t-1}^{k}}{\sum_{k \in E_{i t-1}} X_{i t}^{k}} \sum_{c \in C_{i t}}\left(\frac{X_{i t-1}^{k c}}{X_{i t-1}^{k}}\right) \tau_{t}^{k c}\right]$. Pure domestic firms and pure exporting firms are dropped from all estimates. 
Table 5: Impact of Foreign Tariffs on Scope by Log of Overhead Expenses

\begin{tabular}{lcccc}
\hline \hline Measure of Home Tariffs & \multicolumn{2}{c}{ Firm-Level Tariffs } & \multicolumn{2}{c}{ Industry-Level Tariffs } \\
\cline { 2 - 5 } Regressand: Export Product Scope & $(1)$ & $(2)$ & $(3)$ & $(4)$ \\
\hline Home Tariffs & $0.017^{* * *}$ & $0.019^{* * *}$ & $0.012^{* * *}$ & $0.013^{* * *}$ \\
& $(29.49)$ & $(26.69)$ & $(17.08)$ & $(15.14)$ \\
Foreign Tariffs & $0.003^{* * *}$ & -0.000 & $0.002^{* * *}$ & -0.000 \\
& $(5.61)$ & $(-0.28)$ & $(4.54)$ & $(-0.58)$ \\
Foreign Tariffs $\times$ High Overhead Indicator & $0.689^{* * *}$ & $0.596^{* * *}$ & $0.736^{* * *}$ & $0.607^{* * *}$ \\
& $(12.27)$ & $(9.09)$ & $(12.39)$ & $(8.86)$ \\
Foreign Tariffs $\times$ Low Overhead Indicator & $-0.774^{* * *}$ & -0.284 & $-0.706^{* * *}$ & -0.099 \\
& $(-7.00)$ & $(-1.61)$ & $(-5.81)$ & $(-0.51)$ \\
Firm Input Tariffs & & $0.003^{* * *}$ & & $0.003^{* * *}$ \\
& & $(3.16)$ & & $(3.58)$ \\
Log Firm TFP (TFP2) & $0.036^{* * *}$ & $0.023^{*}$ & $0.033^{* * *}$ & 0.019 \\
& $(3.02)$ & $(1.65)$ & $(2.63)$ & $(1.33)$ \\
Log Weighted GDP of Importers & $0.132^{* * *}$ & $0.122^{* * *}$ & $0.134^{* * *}$ & $0.124^{* * *}$ \\
& $(80.31)$ & $(62.52)$ & $(78.78)$ & $(61.63)$ \\
Foreign Indicator & $0.105^{* * *}$ & $-0.030^{* *}$ & $0.101^{* * *}$ & $-0.034^{* *}$ \\
& $(9.96)$ & $(-2.14)$ & $(9.22)$ & $(-2.40)$ \\
SOE Indicator & 0.032 & 0.038 & 0.005 & 0.002 \\
& $(1.12)$ & $(1.08)$ & $(0.18)$ & $(0.04)$ \\
Processing Indicator & $-0.029^{* * *}$ & $-0.060^{* * *}$ & $-0.023^{* * *}$ & $-0.054^{* * *}$ \\
Firm-specific Fixed Effects & $(-4.78)$ & $(-10.17)$ & $(-3.59)$ & $(-8.86)$ \\
Year-specific Fixed Effects & Yes & Yes & Yes & Yes \\
Observations & Yes & Yes & Yes & Yes \\
\hline
\end{tabular}

Note: Robust t-values corrected for clustering at the firm level in parentheses. ${ }^{*}(*)$ indicates significance at the 10(5) percent level. Here home tariffs in Columns (1)-(2) are measured by Eq. (20) whereas those in Columns (3)-(4) are industry-level tariffs. Foreign tariffs are measured by Eq. (21). High overhead indicator in Columns (1)-(4) equals one if firm's log of overhead expenses is higher than top $25^{\text {th }}$ quantile of $\log$ of overhead expenses and zero otherwise. Analogously, low overhead indicator in Columns (1)-(4) equals one if firm's log of overhead expenses is lower than bottom $25^{\text {th }}$ quantile of log of overhead expenses and zero otherwise. Pure domestic firms and pure exporters are dropped from all estimates. 


\section{Table 6: Impact of Foreign Tariffs on Scope by Per-Capita Overhead}

Expenses

\begin{tabular}{lcccc}
\hline \hline Measure of Home Tariffs & \multicolumn{2}{c}{ Firm-Level Tariffs } & \multicolumn{2}{c}{ Industry-Level Tariffs } \\
\cline { 2 - 5 } Regressand: Export Product Scope & $(1)$ & $(2)$ & $(3)$ & $(4)$ \\
\hline Home Tariffs & $0.017^{* * *}$ & $0.018^{* * *}$ & $0.012^{* * *}$ & $0.012^{* * *}$ \\
Foreign Tariffs & $(29.08)$ & $(26.24)$ & $(16.49)$ & $(14.55)$ \\
& $0.006^{* * *}$ & $0.004^{* * *}$ & $0.006^{* * *}$ & $0.003^{* * *}$ \\
Foreign Tariffs $\times$ High Overhead Indicator & $(13.99)$ & $(7.63)$ & $(13.83)$ & $(7.13)$ \\
& $0.441^{* * *}$ & $0.265^{* * *}$ & $0.432^{* * *}$ & $0.298^{* * *}$ \\
Foreign Tariffs $\times$ Low Overhead Indicator & $-0.352^{* * *}$ & $-0.281^{* * *}$ & $-0.345^{* * *}$ & $-0.251^{* * *}$ \\
& $(-5.70)$ & $(-4.02)$ & $(-5.39)$ & $(-3.55)$ \\
Firm Input Tariffs & & $0.003^{* * *}$ & & $0.003^{* * *}$ \\
& & $(3.42)$ & & $(3.84)$ \\
Log Firm TFP (TFP2) & $0.032^{* * *}$ & 0.018 & $0.027^{* *}$ & 0.012 \\
& $(2.75)$ & $(1.35)$ & $(2.26)$ & $(0.91)$ \\
Log Weighted GDP of Importers & $0.132^{* * *}$ & $0.121^{* * *}$ & $0.134^{* * *}$ & $0.122^{* * *}$ \\
& $(82.34)$ & $(64.06)$ & $(80.90)$ & $(63.39)$ \\
Foreign Indicator & $0.105^{* * *}$ & $-0.031^{* *}$ & $0.102^{* * *}$ & $-0.035^{* *}$ \\
& $(10.10)$ & $(-2.24)$ & $(9.39)$ & $(-2.46)$ \\
SOE Indicator & $0.047^{*}$ & 0.048 & 0.020 & 0.011 \\
& $(1.68)$ & $(1.39)$ & $(0.69)$ & $(0.31)$ \\
Processing Indicator & $-0.026^{* * *}$ & $-0.057^{* * *}$ & $-0.021^{* * *}$ & $-0.052^{* * *}$ \\
Firm-specific Fixed Effects & $(-4.60)$ & $(-10.18)$ & $(-3.50)$ & $(-8.98)$ \\
Year-specific Fixed Effects & Yes & Yes & Yes & Yes \\
Observations & Yes & Yes & Yes & Yes \\
\hline
\end{tabular}

Note: Robust t-values corrected for clustering at the firm level in parentheses. ${ }^{*}(*)$ indicates significance at the 10(5) percent level. Here home tariffs in Columns (1)-(2) are measured by Eq. (20) whereas those in Columns (3)-(4) are industry-level tariffs. Foreign tariffs are measured by Eq. (21). High overhead indicator in Columns (1)-(4) equals one if firm's per-capita overhead expenses is higher than top $25^{\text {th }}$ quantile of per-capita overhead expenses and zero otherwise. Analogously, low overhead indicator in Columns (1)-(4) equals one if firm's per-capita overhead expenses is lower than bottom $25^{\text {th }}$ quantile of per-capita overhead expenses and zero otherwise. Pure domestic firms and pure exporters are dropped from all estimates. 
Figure 1: Chinese Trading Firms' Export Scope 


\section{Appendix}

\subsection{Appendix A: The Proof}

Proof of $\frac{d \tilde{s}}{d t}=\frac{d \tilde{e}}{d t}>0$.

If $e=s$, the firm's total profit function is

$$
\pi(s)=\int_{0}^{s} \pi_{H}\left(c_{i}\right) d i+\int_{0}^{s} \pi_{F}\left(c_{i}\right) d i-k s .
$$

The first order condition is

$$
\pi^{\prime}(s)=\frac{1}{4 b}(A-m-c-\theta s)^{2}+\frac{1}{4 b}\left(A^{*}-m-c t^{*}-\theta t^{*} s\right)^{2}-k=0 .
$$

We denote $\pi_{H}(s)=\frac{1}{4 b}(A-m-c-\theta s)^{2}, \pi_{F}(s)=\frac{1}{4 b}\left(A^{*}-m-c t^{*}-\theta t^{*} s\right)^{2}, \pi_{T}(s)=$ $\pi_{H}(s)+\pi_{F}(s)$, and draw all $\pi_{T}(s), \pi_{H}(s)$ and $\pi_{F}(s)$ along with $k$ in Figure 1 . The equilibrium $\tilde{s}$ is determined by the intersection between $\pi_{T}(s)$ and $k$. Should the optimal scope be determined by $\pi_{H}(s)=k$, it would be $\tilde{s}^{\prime}$. We have shown in the text that $\frac{d \tilde{s}^{\prime}}{d t}>0$. That is, when there is a cut in Chinese tariff, $\tilde{s}^{\prime}$ decreases, which implies that the curve $\pi_{H}(s)$ shifts downwards. However, the domestic tariff cut does not affect the curve $\pi_{F}(s)$. Hence, the total profit curve $\pi_{T}(s)$ shifts downwards as well. As a result, $\tilde{s}$ decreases, that is, $\frac{d \tilde{s}}{d t}>0$.

\subsection{Appendix B: Matching Transaction-Level Trade Data and Firm- Level Production Data}

To investigate the impact of firm-specific tariffs on exporter scope, we need to match the three data sets together: transaction-level trade data, firm-level production data, and harmonized system 6-digit level tariffs data.

\subsubsection{Transaction-Level Trade Data Set}

The extremely disaggregated transaction-level monthly trade data during 2000-2006 are obtained from China's General Administration of Custom. Each transaction is described at the HS 8-digit level. The number of monthly observations increases from around 78 thousand in January 2000 to more than 230 thousand in December 2006. As shown in Column (1) of Table A1, the annual number of observations is more than 10 million in 2000 to 16 million in 2006, ending with a huge number of observations, 118,333,831, in total for seven years. Column (2) of Table A1 exhibits that there are 286,819 firms that ever engage in international trade during this period.

For each transaction, the data set compiles three types of information: (1) 5 variables on basic trade information. This includes value (measured at US current dollar), trade status (export or import), quantity, trade unit, value per unit (i.e., value divided by quantity). (2) There are 6 variables on trade mode and pattern. These include country of destination for exports, country of origin for imports, routing (i.e., whether the product is shipped through an intermediate country/regime), customs regime (e.g., processing trade or ordinary trade), trade mode (i.e., by sea, by truck, by air, or by post), customs port 
Figure 1: Adjustment to Tariff Cuts 
(i.e., where the product departs or arrives). (3) More importantly, the data set also reports firm's information associated with the transaction. In particular, it includes 7 variables such as firm's name, identification number set by the customs, city in China where the firm is located, telephone, zip code, name of the manager/CEO, ownership type of firm (e.g., foreign affiliate, private, or state-own-enterprises).

\subsubsection{Firm-Level Production Data Set}

The sample used in this paper comes from a rich firm-level panel dataset which covers around 230,000 manufacturing firms per year for the years 2000-2006. The number of firms doubled from 162,885 in 2000 to 301,961 in 2006. The data are collected and maintained by China's National Bureau of Statistics in an annual survey of manufacturing enterprises. It contains entire information of three accounting sheets (i.e., Balance Sheet, Loss \& Benefit Sheet, and Cash Flow Sheet). On average, the annual entire value of industrial production covered in such a data set accounts for around $95 \%$ of China's total industrial production by year. Indeed, aggregated data on the industrial sector in the annual China's Statistical Yearbook by the Natural Bureau of Statistics (NBS) are compiled from this dataset. The dataset includes more than 100 financial variables listed in the main accounting sheets of all these firms. Briefly, it covers two types of manufacturing firms: (1) all SOEs; (2) nonSOEs whose annual sales are more than five million RMB. The number of firms increased from more than 160 thousand in 2000 to 301 thousand in 2006. As shown in Column (3) of Table A1, the number of firms that ever occurred in the dataset during 2000-2006 is 615,951 in total.

However, the raw production data set is still quite noisy given that many unqualified firms are included, largely because of mis-reporting by some firms. For example, information on some family-based firms, which usually have no formal accounting system in place, is based on a unit of one RMB, whereas the official requirement is a unit of 1000 RMB. We hence filter the raw production data as introduced in the text. Accordingly, the total number of firms covered in the data set is reduced to 438,165 , around $1 / 3$ of firms are dropped from the sample after such a filter process. As shown in Column (4) of Table A1, such a filter ratio is even higher in the initial years: around $1 / 2$ of firms are dropped in 2000 .

\subsubsection{Matching Method}

Although these two data sets have rich information on production and trade, it is challenging to match them together. Both data sets contain a variable of firm's identification number. But their coding systems are completely different and share no any common characteristics. For example, the lengths of the firm's ID variable in transaction-level data set are 10 digits whereas those in firm-levels only have 9 digits. China's customs administration just constructs a complete coding system different from the one adopted by the National Bureau of Statistics.

To address this challenge, we use two ways to match transaction-level trade data and firm-level production data. First, we match two data sets by firm's name and year. That is, if a firm has an exact Chinese name in both data sets in a particular year, they should be an identical firm. The year variable is necessary to use for an auxiliary identification variable since some firms could change their name in different years and new comers could possible take their original name. As a result, the number of matching firm is 83,679 in total by using the raw production data set, and reduced to 69,623 in total by using the more accurate filtered production data set.

Equally importantly, we then use another matching technique to serve as a supplement. Here we rely on two other common variables to identify firms, namely, zip code and 
the last seven digits of a firm's phone number. The rationale is that firms should have different and unique phone numbers within a postal district. Although this method seems straightforward, subtle technical and practical difficulties still remain. For example, the phone numbers in the product-level trade data include both area phone codes and a hyphen, whereas those in the firm-level production data do not. Therefore, we use the last seven digits of the phone number to serve a proxy for firm identification for two reasons: (1) during 2000-2006, some large Chinese cities changed their phone number digits from seven to eight, which usually added one more digit at the start of the number. Therefore, sticking to the last seven digits of the number would not confuse the firm's identification; and (2) in the original data set, phone number is defined as a string of characters with the phone zip code. However, it is inappropriate to de-string such characters to numerals since a hyphen bar is used to connect the zip code and phone number. Using the last seven-digit substring solves this problem neatly.

A firm could miss its name information in either trade or production data set. Similarly, a firm could lose information on phone and/or zip code. To secure that our matched data set can cover common firms as many as possible, we then include the observations in the matched data set if a firm occurred in either the name-adopted matched data set or the phone-and-post-adopted matched data set. As a result, the number of matched firms increases to 90,558 when the raw production data set is used, as shown in Column (7) of Table A1. By way of comparison, such a matching performance is in the same magnitude to (or even better than) other similar studies. For example, Ge et.al. (2011) used the same data sets and similar matching techniques but ends up with 86,336 matched firms in total. Finally, if we adopt the more rigorous filtered production data to merge with firm data, the matched data set ends up with 76,823 firms in total, as shown in the last column of Table A1.

\subsection{Appendix C: Measuring Ex-ante TFP (TFP2)}

This section draws heavily from Feenstra et al. (2013). We extend the Olley-Pakes approach is extended by adding the firm's export decision and a WTO indicator as two extra arguments of the investment function $V_{i t}=g_{1}\left(x_{i t}, \ln K_{i t}, E X_{i t}, P E_{i t}, W T O_{t}\right)$ where $E X_{i t}\left(P E_{i t}\right)$ is the export (processing export) indicator to measure whether firm $i$ exports (engages in processing exports) in year $t$, and $W T O_{t}$ is an indicator that equals one if the WTO agreement has occurred after 2001 and zero before that. Therefore, inverting the investment function with respect to its first argument we obtain: ${ }^{22}$

$$
x_{i t}=g_{1}^{-1}\left(V_{i t}, \ln K_{i t}, E X_{i t}, P E_{i t}, W T O_{t}\right) .
$$

Given the gross production function

$$
\ln Y_{i t}=\alpha_{k} \ln K_{i t}+\alpha_{l} \ln L_{i t}+\alpha_{m} \ln M_{i t}+x_{i t}+\varepsilon_{i t}
$$

and defining the function $g_{2}(\cdot)$ as $\alpha_{k} \ln K_{j t}+g_{1}^{-1}\left(V_{i t}, \ln K_{i t}, E X_{i t}, P E_{i t}, W T O_{t}\right)$, the estimation of the labor (materials) coefficients $\alpha_{l}\left(\alpha_{m}\right)$ are obtained as:

$$
\ln Y_{i t}=\alpha_{l} \ln L_{i t}+\alpha_{m} \ln M_{i t}+g_{2}\left(V_{i t}, \ln K_{i t}, E X_{i t}, P E_{i t}, W T O_{t}\right)+\varepsilon_{i t} .
$$

The next step is to obtain an unbiased estimated coefficient of $\alpha_{k}$. Olley-Pakes use the following specification:

$\ln Y_{i t}-\hat{\alpha}_{l} \ln L_{i t}-\hat{\alpha}_{m} \ln M_{i t}=\alpha_{k} \ln K_{i t}+E\left(x_{i t} \mid x_{i t-1}, p r_{i t}\right)+\left[x_{i t}-E\left(x_{i t} \mid x_{i t-1}, p r_{i t}\right)\right]+\varepsilon_{i t}$,

\footnotetext{
${ }^{22}$ Olley and Pakes (1996) show that the investment demand function is monotonically increasing in the productivity shock $x_{j t}$, by making some mild assumptions about the firm's production technology.
} 
where the estimated values of the labor coefficient and materials coefficient are used on the left. The expectation of productivity appearing in (29) is modeled as a forth-order polynomial function of lagged productivity, which can be obtained as $\left(g_{2 i, t-1}-\alpha_{k} \ln K_{i, t-1}\right)$, and also the predicted probability of the firm's survival into the year $t, p r_{i t}$, based on year $t-1$ information. The predicted probability is obtained from Probit estimation. ${ }^{23}$ The term $\left[x_{i t}-E\left(x_{i t} \mid x_{i t-1}, p r_{i t}\right)\right]$ is the productivity shock for surviving firms, but does not affect the investment or exit choice so it is treated as an error.

We estimate TFP1 and TFP2 using our matched firms. Given that the measure of TFP requires real terms of firm's inputs (labor and capital) and output, we adopt different price deflators for inputs and outputs from Brandt et al. (2012) in which the output deflators are constructed using "reference price" information from China's Statistical Yearbooks whereas input deflators are constructed based on output deflators and China's national input-output table (2002). Secondly, we take China's WTO accession in 2001 into account since such a positive demand shock would push Chinese firms to expand their economic scales, which in turn can exaggerate the simultaneous bias of their measured TFP. Thirdly, it is essential to construct the real investment variable when using the Olley-Pakes (1996) approach. As usual, we adopt the perpetual inventory method to investigate the law of motion for real capital and real investment. Different from assigning an arbitrary number for the depreciation ratio, we use the exact firm's real depreciation provided by the Chinese firm-level data set. Finally, we also consider firm's processing behavior in the TFP realization by constructing a processing export indicator (one denotes processing export and zero otherwise). The idea is that processing firms may use different technology than non-processing firms (Feenstra and Hanson, 2005).

\footnotetext{
${ }^{23}$ Note that here the non-linear least squares approach is adopted to estimate (29) since it requires the estimated coefficients of the log-capital in the first and second term to be identical (Pavcnik, 2002).
} 
Table A1: Matched Statistics-Number of Firms

\begin{tabular}{|c|c|c|c|c|c|c|c|c|}
\hline \multirow{4}{*}{$\begin{array}{l}\text { Year } \\
\# \text { of }\end{array}$} & \multicolumn{2}{|l|}{ Trade Data } & \multicolumn{2}{|c|}{ Production Data } & \multicolumn{4}{|c|}{ "Matched Data } \\
\hline & Transactions & Firms & Raw & Filtered & w/ Raw & w/ Filtered & w/ Raw & $\mathrm{w} /$ Filtered \\
\hline & & & Firms & Firms & Firms & Firms & Firms & Firms \\
\hline & $(1)$ & $(2)$ & $(3)$ & (4) & $(5)$ & (6) & $(7)$ & $(8)$ \\
\hline 2000 & $10,586,696$ & 80,232 & 162,883 & 83,628 & 18,580 & 12,842 & 21,665 & 15,748 \\
\hline 2001 & $12,667,685$ & 87,404 & 169,031 & 100,100 & 21,583 & 15,645 & 25,282 & 19,091 \\
\hline 2002 & $14,032,675$ & 95,579 & 181,557 & 110,530 & 24,696 & 18,140 & 29,144 & 22,291 \\
\hline 2003 & $18,069,404$ & 113,147 & 196,222 & 129,508 & 28,898 & 21,837 & 34,386 & 26,930 \\
\hline 2004 & $21,402,355$ & 134,895 & 277,004 & 199,927 & 44,338 & 35,007 & 50,798 & 40,711 \\
\hline 2005 & $24,889,639$ & 136,604 & 271,835 & 198,302 & 44,387 & 34,958 & 50,426 & 40,387 \\
\hline 2006 & $16,685,377$ & 197,806 & 301,960 & 224,854 & 53,748 & 42,833 & 59,133 & 47,591 \\
\hline All Year & $118,333,831$ & 286819 & 615,951 & 438,165 & 83,679 & 69,623 & 90,558 & 76,946 \\
\hline
\end{tabular}

Notes: Column (1) reports number of observations of HS eight-digit monthly transaction-level trade data from China's General Administration of Customs by year. Column (2) reports number of firms covered in the transaction-level trade data by year. Column (3) reports number of firms covered in the firm-level production dataset compiled by China's National Bureau of Statistics without any filter and cleaning. By contrast, Column (4) presents number of firms covered in the firm-level production dataset with careful filter according to the requirement of GAAP. Accordingly, Column (5) reports number of matched firms using exactly identical company's names in both trade dataset and raw production dataset. By contrast, Column (6) reports number of matched firms using exactly identical company's names in both trade dataset and filtered production dataset. Finally, Column (7) reports number of matched firms using exactly identical company's names and exactly identical zip code and phone numbers in both trade dataset and raw production dataset. By contrast, Column (8) reports number of matched firms using exactly identical company's names and exactly identical zip code and phone numbers in both trade dataset and filtered production dataset. 
Appendix Table A2: Total Factor Productivity of Chinese Firms

\begin{tabular}{|c|c|c|c|c|c|}
\hline Adjusted Chinese Industrial Classfications & Labor & Capital & Materials & TFP1 & TFP2 \\
\hline Processing of Foods (13) & 0.077 & 0.060 & 0.814 & 1.191 & 1.231 \\
\hline Manufacturing of Foods (14) & 0.055 & 0.071 & 0.857 & 0.799 & 0.838 \\
\hline Manufacture of Beverages (15) & 0.094 & 0.113 & 0.799 & 0.817 & 0.830 \\
\hline Manufacture of Tobacco (16) & 0.020 & 0.270 & 0.783 & 0.287 & 0.185 \\
\hline Manufacture of Textile (17) & 0.066 & 0.044 & 0.868 & 0.802 & 0.857 \\
\hline Manufacture of Apparel, Footwear \& Caps (18) & 0.110 & 0.039 & 0.798 & 1.344 & 1.403 \\
\hline Manufacture of Leather, Fur, \& Feather (19) & 0.084 & 0.041 & 0.857 & 0.872 & 0.902 \\
\hline $\begin{array}{l}\text { Processing of Timber, Manufacture of Wood, } \\
\text { Bamboo, Rattan, Palm \& Straw Products (20) }\end{array}$ & 0.099 & 0.071 & 0.841 & 0.686 & 0.717 \\
\hline Manufacture of Furniture (21) & 0.103 & 0.055 & 0.814 & 1.113 & 1.124 \\
\hline Manufacture of Paper \& Paper Products (22) & 0.063 & 0.053 & 0.867 & 0.781 & 0.792 \\
\hline Printing, Reproduction of Recording Media (23) & 0.065 & 0.068 & 0.815 & 1.199 & 1.290 \\
\hline $\begin{array}{l}\text { Manufacture of Articles For Culture, Education } \\
\& \text { Sport Activities }(24)\end{array}$ & 0.091 & 0.039 & 0.823 & 1.181 & 1.219 \\
\hline Processing of Petroleum, Coking, \&Fuel (25) & 0.014 & 0.069 & 0.865 & 0.663 & 0.642 \\
\hline Manufacture of Raw Chemical Materials (26) & 0.063 & 0.058 & 0.820 & 1.187 & 1.218 \\
\hline Manufacture of Medicines (27) & 0.062 & 0.064 & 0.790 & 1.555 & 1.643 \\
\hline Manufacture of Chemical Fibers (28) & 0.040 & 0.060 & 0.889 & 0.517 & 0.584 \\
\hline Manufacture of Rubber (29) & 0.087 & 0.081 & 0.769 & 1.404 & 1.469 \\
\hline Manufacture of Plastics (30) & 0.069 & 0.046 & 0.836 & 1.094 & 1.155 \\
\hline Manufacture of Non-metallic Mineral goods (31) & 0.046 & 0.059 & 0.844 & 1.054 & 1.129 \\
\hline Smelting \& Pressing of Ferrous Metals (32) & 0.061 & 0.029 & 0.891 & 0.682 & 0.766 \\
\hline Smelting \& Pressing of Non-ferrous Metals (33) & 0.080 & 0.079 & 0.850 & 0.451 & 0.497 \\
\hline Manufacture of Metal Products (34) & 0.062 & 0.037 & 0.841 & 1.150 & 1.147 \\
\hline Manufacture of General Purpose Machinery (35) & 0.061 & 0.055 & 0.837 & 1.086 & 1.176 \\
\hline Manufacture of Special Purpose Machinery (36) & 0.053 & 0.049 & 0.841 & 1.152 & 1.191 \\
\hline Manufacture of Transport Equipment (37) & 0.063 & 0.045 & 0.835 & 1.290 & 1.394 \\
\hline Electrical Machinery \& Equipment (39) & 0.077 & 0.066 & 0.836 & 0.900 & 0.913 \\
\hline Computers \& Other Electronic Equipment (40) & 0.109 & 0.075 & 0.806 & 1.175 & 1.243 \\
\hline $\begin{array}{l}\text { Manufacture of Measuring Instruments \& Ma- } \\
\text { chinery for Cultural Activity \& Office Work (41) }\end{array}$ & 0.049 & 0.054 & 0.806 & 1.639 & 1.703 \\
\hline Manufacture of Artwork (42) & 0.091 & 0.039 & 0.857 & 0.834 & 0.839 \\
\hline
\end{tabular}

Notes: We do not report standard errors for each coefficient to save space though available upon request. The logarithm of firm productivity for Chinese firms (TFP1 and TFP2) is estimated by industry by the augmented Olley-Pakes approach introduced in the text. Coefficients of labor, capital, and materials are calculated at the sectoral average whereas TFP1 and TFP2 is measured at firm-level using firm-level output, capital, labor, and materials,respectively. 